\title{
CORPORATIONS AND RELIGIOUS FREEDOM: HOBBY LOBBY STORES-A MISSED OPPORTUNITY TO RECONCILE A FLAWED LAW WITH A FLAWED HEALTH CARE SYSTEM
}

\author{
MATTHEW A. MELONE*
}

"It is truly enough said, that a corporation has no conscience; but a corporation of conscientious men is a corporation with a conscience."

Henry David Thoreau* ${ }^{* *}$

"Corporation, $\mathrm{n}$. An ingenious device for obtaining individual profit without individual responsibility"

$$
\text { Ambrose Bierce }{ }^{* * *}
$$

On June 30, 2014, the Supreme Court held, in Burwell v. Hobby Lobby Stores, Inc., ${ }^{1}$ that the requirement that employer group health insurance plans provide coverage for certain contraception products or services violated the religious free exercise rights of three closely-held corporations. ${ }^{2}$ The contraception mandate was imposed by regulations implementing the Patient Protection and Affordable Care Act, ${ }^{3}$ itself a very controversial piece of legislation, a part of which was upheld recently by the Court in a perhaps even more controversial case. ${ }^{4}$ The religious rights at issue were protected by a two decades old statute enacted in the aftermath of another controversial Court decision that significantly curtailed First Amendment protection for religious free exercise when such exercise runs counter to the strictures of a law of general applicability. ${ }^{5}$

The Patient Protection and Affordable Care Act intruded - some would say rather rudely-into what theretofore was the private matter of whether an employer offered its employees health insurance coverage as part of their compensation package. ${ }^{6}$ Most employers of significant size must offer such coverage or face the possible imposition of significant financial penalties. ${ }^{7}$

* Professor of Law, Lehigh University, Bethlehem, Pennsylvania.

** Henry David Thoreau, Resistance To Civil Government 190-91 (1849) (emphasis in original).

*** Ambrose Bierce, The Devil's Dictionary 23 (1911), available at http://www. commissionedwriting.com/THE\%20DEVILS\%20DICTIONARY\%20AMBROSE\%20BIERCE.pdf, archived at http://perma.cc/ZQ9J-784Q.

1. Burwell v. Hobby Lobby Stores, Inc., 134 S. Ct. 2751 (2014). Two cases were before the Court, Burwell v. Hobby Lobby Stores, Inc. on writ of certiorari to the Tenth Circuit and Conestoga Wood Specialties Corp. v. Burwell on writ of certiorari to the Third Circuit. See infra notes 59-76 and accompanying text.

2. Id. at 2759 .

3. Pub. L. No. 111-148, 124 Stat. 119 (2010).

4. See infra notes 27-28 and accompanying text.

5. See infra notes $45-58$ and accompanying text.

6. I.R.C. $\S 4980 \mathrm{H}$ (CCH 2014).

7. See id. $\S 4980 H(c)(D)$. 
Moreover, in addition to mandating the benefit itself, the legislation also dictated what types of products or services must be included within the mandated coverage. ${ }^{8}$ One such mandated product or service is contraception. ${ }^{9}$

Individual health care decisions are highly personal, but not entirely private, matters. Most individual health care services are paid by an insurer thereby interjecting a third party into the patient-physician relationship. ${ }^{10}$ Quite often disputes arise between the insured and insurer regarding policy coverages. ${ }^{11}$ However, these disputes, invariably, are financial in nature. ${ }^{12}$ By dint of economic measures necessitated by the demands of World War II, employerprovided health insurance is a significant fixture in the delivery of health care in the United States. ${ }^{13}$ Consequently, many health care decisions also involve an employer whose interests may or may not coincide with the needs of individual employees. ${ }^{14}$ Employer-employee conflicts are routine but, similar to insuredinsurer disputes, they generally are financial in nature. ${ }^{15}$ The conflict generated by the contraception mandate is one that implicates religion and the reproductive rights of women. ${ }^{16}$ By themselves, these are highly-charged issues. In combination, they are legally combustible. Hobby Lobby Stores is the opening salvo in what promises to be a contentious political and legal war between two uncompromising sides that hold their competing values dear.

Part I of this Article provides an overview of the contraception mandate and the Religious Freedom Restoration Act ("RFRA"), the statute enacted to reinstate the religious protections that Congress believed the Court had abdicated in an earlier decision. ${ }^{17}$ Part II analyzes the Court's decision in Hobby Lobby Stores..$^{18}$ The Court, in its most controversial holding, stated that for-profit corporations enjoy the protections provided by RFRA. ${ }^{19}$ It then proceeded to examine whether

8. 42 U.S.C.A. § 18022 (2014).

9. 42 U.S.C. $§ 300 g g-13$ (a)(4) (2010).

10. See Thomas C. Buchmueller \& Alan C. Monheit, Employer-Sponsored Health Insurance and the Promise of Health Insurance Reform 1 (Nat'l Bureau of Econ. Research, Working Paper No. 14389, 2009).

11. Handling an Insurance Dispute, Ctr. for Advancing Health (June 2013), http://www.cfah.org/prepared-patient/pay-for-your-health-care/handling-an-insurance-dispute, archived at $\mathrm{http}: / /$ perma.cc/CLS3-ER25.

12. Id.

13. Buchmueller \& Monheit, supra note 10, at 3.

14. Report of the Working Group on Challenges to the Employment-Based Healthcare System, United States Dep't of Labor (Nov. 14, 2001), http://www.dol.gov/ebsa/publications/ AC_1114b01_report.html, archived at http://perma.cc/MD7T-CZ4P.

15. Id.

16. Karen Finney, Hobby Lobby Opens a New Front in the 'War on Women, 'MSNBC (July 13, 2014, 9:11 AM) http://www.msnbc.com/msnbc/hobby-lobby-opens-new-front-the-war-women, archived at $\mathrm{http}: / /$ perma.cc/235W-XFNG.

17. Pub. L. No. 103-141, 107 Stat. 1488 (1993).

18. Burwell v. Hobby Lobby Stores, Inc., 134 S. Ct. 2751 (2014).

19. Id. at 2775 . 
the contraception mandate violated RFRA. ${ }^{20}$ According to the majority, the contraception mandate placed a substantial burden on the corporations' right to free exercise and that the government had other, less restrictive, means at its disposal to accomplish what the mandate was designed to achieve. ${ }^{21}$ This part also analyzes Justice Ginsburg's vigorous dissent. ${ }^{22}$

Part III critiques the Court's decision. This part takes exception with the Court's reasoning with respect to corporate rights and asserts that individual and corporate rights exist for different reasons and these differences justify the denial of certain rights in a corporate context. Moreover, the recognition of corporate rights by derivation from individual rights of association misunderstands the nature of the modern corporation. Part III also argues that the Court should have used this occasion to place some principled limitation on the concept of the "exercise" of religion. RFRA protects free exercise but does not insure the presence of a clear conscience. ${ }^{23}$ Alternatively, the Court should have scrutinized the claim that the burden imposed by the contraception mandate was substantial by reference to some objective standard. Unfortunately, the Court's failure to do either insures that courts will reach the final prong of the statute - the least restrictive means test. ${ }^{24}$ In this respect, Hobby Lobby Stores was an abdication of the judicial humility that the Court displayed in the seminal case of Chevron U.S.A., Inc. v. Natural Resources Defense Council, Inc. ${ }^{25}$

\section{The CONTRACEPTION MANDATE \& RFRA: AN OVERVIEW}

The Patient Protection and Affordable Care Act, a broad and controversial piece of legislation that enacted sweeping changes to the health care industry was signed into law by President Obama on March 23, 2010. ${ }^{26}$ In 2012 the United States Supreme Court, in National Federation of Independent Business v. Sebelius, upheld the constitutionality of the individual mandate, the requirement, upon pain of financial penalty, that individuals obtain health insurance

\section{Id.}

21. Id. at $2779-82$.

22. Id. at $2783-85$.

23. Id. at 2789 .

24. Id. at 2780.

25. Chevron U.S.A., v. Natural Res. Def. Council, 467 U.S. 837 (1984).

26. The Act, among its many provisions, imposed reforms on the health insurance industry, expanded Medicaid, enacted changes to Medicare, introduced illness prevention programs, and imposed a host of penalties, taxes, and other assessments on individuals and employers. This legislation "includes the largest set of tax law changes in more than 20 years." TREAS. INSPECTOR Gen. For Tax Admin., Ref. No. 2012-43-064, AfFordable Care Act: Planning EfForts For The tax Provisions of The Patient Protection and Affordable Care Act Appear AdeQuate; However, THE Resource Estimation Process NeEds IMProvement, Highlights (2012); see also Fla. v. U.S. Dep't of Health and Human Serv., 648 F.3d 1235, 1248-49 (11th Cir. 2011) (providing a succinct discussion of the scope of the legislation). 
coverage. ${ }^{27}$ The Court held that the imposition of the individual mandate was

27. Nat'l Fed'n of Indep. Bus. v. Sebelius, 132 S. Ct. 2566 (2012). The Act added section 5000A to the Internal Revenue Code. Pub. L. No. 111-148, §§ 1501(b), 10106(b)(1), 124 Stat. 119 , 244-49, 909-10 (2010) (codified as amended at I.R.C. $§ 5000 \mathrm{~A}$ ). The penalty amount imposed by the statute was amended shortly thereafter by the Health Care and Education Reconciliation Act of 2010, Pub. L. No. 111-152, § 1002, 124 Stat. 1029, 1032-33 (2010) (codified at I.R.C. § 5000A). The statute requires that an applicable individual maintain minimum essential coverage for such individual and any dependents who are also applicable individuals each month beginning after 2013. I.R.C. $\S 5000 \mathrm{~A}(\mathrm{a})$ (2014). An applicable individual is an individual other than an individual who qualifies for statutorily defined religious conscience or health ministry exemptions, is not a citizen or national of the United States or a legal alien present in the United States, or is incarcerated. $I d$. $\S 5000 \mathrm{~A}(\mathrm{~d})$. Individuals whose required contribution exceeds eight percent of household income, individuals with very low income, and members of Indian tribes are not subject to the penalty. $I d$. $\S 5000 \mathrm{~A}(\mathrm{e})(1)-(3)$. Hardship exemptions are also available. See Treas. Reg. $\S$ 1.5000A-3(h) (2013); Cong. Budget Office, Payments Of Penalties For Being Uninsured UNDER THE AFFORDABLE CARE ACT: 2014 UPDATE (2014) (projecting that a significant number of individuals will be eligible for hardship exemptions), available at http://www.cbo.gov/sites/default/files/cbofiles/attachments/45397-IndividualMandate.pdf, archived at http://perma.cc/EL9T-VWKV. Failure to meet this requirement for one or more months results in the imposition of a shared responsibility payment. I.R.C. $\S 5000 \mathrm{~A}(\mathrm{~b})(1)$ (2014). The shared responsibility payment is termed a penalty that is to be included with a taxpayer's income tax return for the taxable year which includes the month that such failure occurred. $I d$. $\S 5000 \mathrm{~A}(\mathrm{~b})(1)-(2)$. The requirement to maintain minimum essential coverage is variously met through, among other means, Medicare or Medicaid coverage, individual insurance policies, or eligible employersponsored group health plans or insurance coverage. $I d$. $\S 5000 \mathrm{~A}(\mathrm{f})$. The amount of the penalty due for a taxable year is the lesser of the sum of the monthly penalty amounts or the amount of the national average insurance premiums for a particular level of coverage for the applicable family size involved offered through insurance Exchanges. Id. $\S 5000 \mathrm{~A}(\mathrm{c})(1)$. The monthly penalty amount is one-twelfth of the greater of a flat dollar amount or a percentage of income. Id. $\S$ $5000 \mathrm{~A}(\mathrm{c})(2)$. The flat dollar amount is $\$ 95$ per individual failure in 2014 increasing to $\$ 325$ per individual failure in 2015 and then settling at $\$ 695$ per individual failure thereafter. Id. $\S \S$ $5000 \mathrm{~A}(\mathrm{c})(2)(\mathrm{A}), 5000 \mathrm{~A}(\mathrm{c})(3)(\mathrm{A})-(\mathrm{B})$. The total flat dollar amount penalty cannot exceed $300 \%$ of the individual amounts. $I d . \S 5000 \mathrm{~A}(\mathrm{c})(2)(\mathrm{A})(\mathrm{ii})$. The tax base for the percentage of income penalty amount is the taxpayer's household income in excess of the amount of gross income that is necessary to impose a duty on the taxpayer to file an income tax return. $I d$. $\S \S 5000 \mathrm{~A}(\mathrm{c})(2)(\mathrm{B})$, 6012(a)(1). For this purpose, household income is the modified adjusted gross income of the taxpayer and all dependents that are required to file a tax return for the year in question. Id. $\S$ $5000 \mathrm{~A}(\mathrm{c})(4)(\mathrm{B})$. Modified adjusted gross income is adjusted gross income increased by certain foreign income and tax-exempt interest. $I d$. $5000 \mathrm{~A}(\mathrm{c})(4)(\mathrm{C})$. The penalty is equal to one percent of the tax base in 2014, two percent of the tax base in 2015, and two and one-half percent of the tax base thereafter. $I d$. $\S 5000 \mathrm{~A}(\mathrm{c})(2)(\mathrm{B})$. It is likely that the penalty will be determined by a percentage of income for families of moderate to moderately high income. Lower income families will likely be subject to a flat dollar amount penalty. Very low income families are exempted from the penalty. High income families will likely find themselves subject to a penalty that is based on the cost of insurance coverage and, depending on their household income, incur the maximum 
impermissible under the commerce power but that such imposition was a proper exercise of Congress' taxing power. ${ }^{28}$ The challenge to the individual mandate engendered the most sustained media scrutiny of a United States Supreme Court case in recent memory.

Less notoriety attached to the Act's addition of section $4980 \mathrm{H}$ to the Internal Revenue Code. ${ }^{29}$ This provision imposes an exaction on certain employers if they either do not offer insurance coverage to their employees or offer coverage that is deemed inadequate under the statute. ${ }^{30}$ The constitutionality of this provision was not before the Court in National Federation of Independent Business v. Sebelius. ${ }^{31}$ An assessable payment is imposed on large employers, those with an average of fifty or more full-time or full-time equivalent employees, if such employers fail to offer minimum essential health care coverage to full-time employees. ${ }^{32}$ Failure to offer such coverage results in the imposition of a penalty,

penalty for failure to obtain insurance for a portion of the year.

28. Sebelius, 132 S. Ct. at 2593. Seven Justices also held that the statute's expansion of Medicaid was impermissibly coercive to the states and held that states could opt to decline to expand Medicaid eligibility without the loss of federal funds provided under existing programs. See id. at 2606-07. A related provision that prohibits a state from restricting existing Medicaid eligibility requirements prior to the establishment of its state Exchange was not at issue in this case. See Patient Protection and Affordable Care Act, Pub. L. No. 111-148, § 2001(b), 124 Stat. 275 (2010).

29. Patient Protection and Affordable Care Act, Pub. L. No. 111-148, §§ 1513, 10106(e), 124 Stat. 253-56, 910-11 (2010) (codified as amended in I.R.C. § 4980H (2014)).

30. See generally I.R.C. $§ 4980 \mathrm{H}$ (2014).

31. A federal district court upheld the constitutionality, on Commerce Clause grounds, of both the individual and employer mandates, but its decision was vacated by the Fourth Circuit due to the application of the Ant-Injunction Act. See Liberty Univ., Inc. v. Geithner, 753 F. Supp. 2d 611 (W.D. Va., 2010), vacated, Liberty Univ., Inc. v. Geithner, 671 F.3d 391 (4th Cir. 2011). The Anti-Injunction Act prohibits, subject to few exceptions, any "suit for the purpose of restraining the assessment or collection of any tax . . . in any court by any person, whether or not such person is the person against whom such tax was assessed.” I.R.C. § 7421(a) (2014). In Sebelius, the Court also held that despite the status of the individual mandate penalty as a tax for constitutional purposes, the penalty was not a tax for purposes of the Anti-Injunction Act. Sebelius, $132 \mathrm{~S}$. Ct. at 2594. In light of its holding in Sebelius, the United States Supreme Court granted certiorari and remanded the case back to the Fourth Circuit. The Fourth Circuit then held that Liberty University had standing to challenge the employer mandate and upheld the constitutionality of the employer mandate. Liberty Univ., Inc. v. Lew, 733 F.3d 72 (4th Cir. 2013), cert. denied, Liberty Univ., Inc. v. Lew, 134 S. Ct. 683 (2013). Both mandates were also challenged in another case, but the court dismissed the complaint for lack for standing. See N.J. Physicians, Inc. v. Obama, 757 F. Supp. 2d 502 (D.N.J. 2010), aff'd, N.J. Physicians, Inc. v. President of the United States, 653 F.3d 234 (3d Cir. 2011).

32. I.R.C. $\S \S 4980 \mathrm{H}(\mathrm{a})(1), 4908 \mathrm{H}(\mathrm{c})(2)(\mathrm{A})(2014)$. A full-time employee is defined as an employee who is employed an average of at least thirty hours per week. $I d$. $\S 4980 \mathrm{H}(\mathrm{c})(4)(\mathrm{A})$. The full-time equivalency rules apply only for the purposes of determining whether an employer employs an average of fifty or more full time employees. These rules do not apply for purposes 
for each full-time employee in excess of thirty, up to $\$ 2000$ per annum if no coverage is provided and one employee qualifies for a premium tax credit or subsidy. ${ }^{33}$ The maximum annual penalty amount is $\$ 3000$ if unaffordable coverage is offered. ${ }^{34}$ The Obama Administration has twice delayed the

of determining the penalty amount. See id. $\S 4980 \mathrm{H}(\mathrm{c})(2)(\mathrm{E})$. Therefore, if full-time employees number less than thirty there would be no penalty for failure to offer coverage regardless of the number of full time equivalent employees.

33. Id. $\S \S 4980 \mathrm{H}(\mathrm{a}),(\mathrm{c})(1)$. The penalty is assessed at the rate of one twelfth of the aforementioned amount for each month that such penalty is applicable. Id. The Patient Protection and Affordable Care Act segments the health insurance market into four markets: the individual market; two employer provided group insurance markets, the small and large group market, based on the size of the employer; and the Exchanges. Patient Protection and Affordable Care Act, Pub. L. 111-148, $\S 1$ 1304, 1312, 124 Stat. 171, 182 (2010) (codified at 42 U.S.C. $\S \S 18024$, 18032(2010)). The Exchanges are intended to function as insurance marketplaces in which individuals have the ability to comparison shop for insurance products. Qualified employers may also purchase group plans through the Exchanges. Id. § 1311(d)(2), 124 Stat. 176 (codified at 42 U.S.C. $\$ 18031$ (2010)). A state may opt out of creating and operating an Exchange in which case the Exchange will be established by the federal government. Id. § 1321(c), 124 Stat. at 186 (codified at 42 U.S.C. $\S 18041$ ). Federal tax credits are provided to individuals and families whose income is below a certain threshold, who do not obtain insurance through their employer, and who purchase insurance through an exchange. I.R.C. $\S 36$ B (2014). Section 36B appears to limit the tax credit to taxpayers who are enrolled in state Exchanges. See id. $\S 36 \mathrm{~B}(\mathrm{~b})(2)$. However, regulations were issued pursuant to which participants in federally assisted Exchanges would also qualify for the credit. See Treas. Reg. $\S \S 1.36 \mathrm{~B}-1(\mathrm{k})$ (2012) (defining Exchange by reference to 45 C.F.R. $\S 155.20$ ); Treas. Reg. $\S \S 1.36 \mathrm{~B}-2$ (a) (2012) (providing eligibility for credit by enrollment in an Exchange); 45 C.F.R. $\S 155.20$ (2012) (stating that the term Exchange refers to state Exchanges, regional Exchanges, subsidiary Exchanges, and a Federally-facilitated Exchange) (emphasis added). These regulations have come under attack. See Louise Radnofsky, Health Law Opponents Challenge Tax Credit, WALL ST. J., July 17, 2012, at A7. Two commentators have asserted that the statute's omission of enrollment in federal Exchanges as a condition for the tax credit was intentional. See Jonathan H. Adler \& Michael F. Cannon, Taxation Without Representation: The Illegal IRS Rule to Expand Tax Credits Under the PPACA, 22-41 (Case Research Paper Series in Legal Studies, Working Paper 2012-27, 2012), available at http://ssrn.com/abstract=2106789, archived at http://perma.cc/6FMB-734C. Two recent district court decisions have upheld the regulations. However, the Fourth and D.C. Circuits split with the former affirming the lower court decision and the latter reversing the lower court decision. See King v. Burwell, 759 F.3d 358 (4th Cir. 2014), aff'g King v. Sebelius, 997 F. Supp. 2d 415 (E.D. Va. 2014); Halpig v. Burwell, 758 F.3d 390 (D.C. Cir. 2014), rev'g Halpig v. Sebelius, Civil Action No. 13-0623 (PLF), 2014 U.S. Dist. LEXIS 4853 (D.D.C. Jan. 15, 2014). Given the circuit court split and the effect that this issue has on a great number of states and taxpayers it is likely that this issue will reach the Court soon. See Louise Radnofsky, States Try to Protect Exchanges From Ruling, WaLl ST. J., July 26, 2014, at A4.

34. I.R.C. $\S \S 4980 \mathrm{H}(\mathrm{a})(1), 4980 \mathrm{H}(\mathrm{b})(1)$ (2014). This penalty also is assessed at the rate of one twelfth of the aforementioned amount for each month that such penalty is applicable. Id. 
enforcement of these provisions. ${ }^{35}$ The delays themselves have generated controversy because the statute does not authorize such delays. ${ }^{36}$ In addition, an

35. See Notice 2013-45, 2013-31 I.R.B. 116 (2013) (delaying enforcement until 2015). In February 2014, final regulations were issued that further delay the enforcement of the employer mandate until 2016 for employers with less than 100 full-time equivalent employees or for those employers with 100 or more full-time equivalent employees that provide affordable health insurance coverage to at least seventy percent of employees. See generally Treas. Reg. $\S \S$ $54.4980 \mathrm{H}-1-54,-6$ (2014). Moreover, employers with 100 or more full-time equivalent employees will not be subject to the full mandate in 2016 if they provide coverage to at least ninety-five percent of employees. Id. The final rules prohibit the application of these transition rules if the employer reduces the size of its workforce or the overall hours of service of its employees between February 9, 2014 and December 31, 2014 in order to qualify for relief under the less than 100 fulltime equivalent employee test. Id. Workforce or hour reductions are permitted for bona fide business reasons. Id. Moreover, transition relief is denied to employers that would otherwise qualify if such employer eliminates or materially reduces health coverage it offered as of February 9, 2014. Id. Employers subject to the mandate for plan years beginning in 2015 will be subject to an assessable payment only for full-time employees in excess of eighty instead of full-time employees in excess of thirty as previously noted.

36. House Republicans are contemplating a lawsuit over the administration's actions. See Michael R. Crittenden \& Colleen McCain Nelson, House Authorizes Boehner to Sue President, Wall St. J., July 31, 2014, at A4; see also Jeremy W. Peters, Partisanship Infuses Hearings on Health Law and Executive Power, N.Y. TIMES, July 17, 2014, at A15. Whether Congress has standing to bring the suit is an open question. The Court has not been amenable to the standing of individual members of Congress to challenge legislation or executive branch actions. In Raines $v$. Byrd, several members of Congress claimed that the Line Item Veto Act unconstitutionally rendered their votes on appropriation bills less effective. Raines v. Byrd, 521 U.S. 811, 816 (1997). Despite the fact that the statute expressly conferred standing to any member of Congress that it adversely affected, the Court held that such injury was not cognizable because it was "wholly abstract and widely dispersed." Id. at 829 . The Court left open the possibility in Raines that an injury that amounted to the complete nullification of the legislators' votes may be cognizable. Id. at 823-25. The possibility that standing could be maintained in the event of vote nullification is based on the case of Coleman v. Miller, in which the Court held that a group of Kansas state legislators had standing to challenge the casting of the deciding vote by the lieutenant governor regarding the ratification of an amendment to the United States Constitution. Coleman v. Miller, 307 U.S. 433 (1939). The Court has not addressed whether Congress or any of its chambers, as a body, has standing to sue to enforce a statute. It has, however, hinted that standing Congress may have. In INS v. Chadha, a federal statute that permitted either house of Congress, by resolution, to overrule a decision by the Immigration and Naturalization Service to allow a deportable alien to remain in the United States was held unconstitutional upon challenge by the petitioner alien. INS v. Chadha, 462 U.S. 919 (1983). The agency agreed with the petitioner's claim, and the Ninth Circuit permitted Congress to intervene and defend the constitutionality of the statute. $I d$. at $923-$ 28. The Court permitted the intervention and stated that "Congress is the proper party to defend the validity of a statute when an agency of government, as a defendant charged with enforcing the statute, agrees with plaintiffs that the statute is inapplicable or unconstitutional." Id. at 939. However, the Court held that the petitioner maintained standing in the case despite the fact that he 
excise tax is imposed in the amount of $\$ 100$ per day for each affected individual if the group health plan does not conform to the requirements of the Patient Protection and Affordable Care Act. ${ }^{37}$

One objective of the Patient Protection and Affordable Care Act is the provision of preventative care for women. ${ }^{38}$ Recommended guidelines were published on August 3, 2011, that included, as part of such preventive care, FDAapproved contraceptive methods for women with discretionary exemptions for churches, their auxiliaries, and religious orders. ${ }^{39}$ After originally providing certain religious non-profit employers with an additional year to comply with the contraception coverage, the Obama Administration, under pressure from various religious groups, announced a compromise whereby insurance companies would provide contraception coverage for employees of certain religious non-profit employers - termed "eligible organizations"-free of charge if the employers decided not to provide such coverage. ${ }^{40}$ No other exemptions or concessions

had prevailed in the lower courts and that the INS agreed with his position. Id. at 930, 939-40. Consequently, it was not necessary for Congress to maintain standing in its own right in order to intervene. United States $v$. Windsor, the recent case that struck down the Defense of Marriage Act, raised standing issues similar to Chadha. United States v. Windsor, 133 S. Ct. 2675 (2013). The Bipartisan Litigation Advisory Group ("BLAG") of the House of Representatives petitioned to intervene to defend the statute and was permitted by the district court to intervene as an interested party. $I d$. at 2684 . The Court held that the petitioner and respondent maintained standing. Id. at 2686. Consequently, the Court did not need to decide whether BLAG had standing its own right despite the fact that BLAG's presence in this case was crucial to its standing holding. $I d$. at 2688. Justices Alito and Thomas, however, believed that BLAG did have standing to defend the statute. "Accordingly, in the narrow category of cases in which a court strikes down an Act of Congress and the Executive declines to defend the Act, Congress has both the standing to defend the undefended statute and is a proper party to do so." Id. at 2714 (Alito, Thomas, J.J., concurring in part, dissenting in part).

37. See I.R.C. $\S \S 4980 D(a)-(b), 9815$ (2014). The excise tax imposed by section 4980D predates the enactment of Patient Protection and Affordable Care Act. The excise tax is triggered by the failure of a plan to conform to the requirements of chapter 100 of the Internal Revenue Code. I.R.C. $§ 4980$ (a) (2014). Internal Revenue Code 9815 was added to chapter 100 by the Patient Protection and Affordable Care Act to incorporate its changes into chapter 100. See Patient Protection and Affordable Care Act, Pub. L. 111-148, Title I, § 1563(f), 124 Stat. 270 (as redesignated by Patient Protection and Affordable Care Act, Pub L. 111-148, Title X, § 10107(b)(1), 124 Stat. 911 (2010).

38. 42 U.S.C. $\S 300 g g-13$ (a)(4) (2010).

39. See 45 C.F.R. § 147.131(a) (2013); see also Group Health Plans and Health Insurance Issuers Relating to Coverage of Preventive Services Under the Patient Protection and Affordable Care Act, 76 Fed. Reg. 46,621, 46,623 (Aug. 3, 2011).

40. See 45 C.F.R. § 147.131(b) (2013); see also Press Release, Office of the Press Sec'y, The White House, Fact Sheet: Women's Preventive Services and Religious Institutions (Feb. 10, 2012) available at http://www.whitehouse.gov/the-press-office/2012/02/10/fact-sheet-women-spreventive-services-and-religious-institutions, archived at http://perma.cc/V8FW-FMYM. This accommodation has itself come under attack. As a result, the Obama Administration recently 
were made for any other persons who object, on religious grounds, to the coverage of contraceptive services. ${ }^{41}$ Grandfathered plans are exempt from this provision without regard to religious objections. ${ }^{42}$ In 2000 , the Equal Employment Opportunity Commission ("EEOC") decided that employers sponsoring group health insurance plans that offer prescription drug coverage but that fail to cover contraceptives were in violation of Title VII of the Civil Rights Act of 1964 as amended by the Pregnancy Discrimination Act. ${ }^{43}$ The contraception mandate at issue in this case offers much broader protection for contraception coverage than Title VII because nothing in Title VII requires employers to offer prescription drug coverage to any employee, male or female, and not all courts have agreed with the EEOC's position. ${ }^{44}$

Prior to 1990, whether exceptions to laws of general applicability were required under the Free Exercise Clause of the First Amendment for religious objectors was judicially determined by balancing the competing interests at stake taking into account, among other factors, whether the government's asserted interest was compelling and the burden imposed on the religious objectors. ${ }^{45}$ For example, in Sherbert v. Verner,${ }^{46}$ the Court determined whether an individual's right to her free exercise of religion had been violated by the government by first determining whether the challenged government action imposed a burden on her ability to act on her religious beliefs. ${ }^{47}$ If so, the government had to prove that it

modified the accommodation. See infra note 160 and accompanying text. The modified accommodation has not placated all objectors. See Louise Radnofsky, Birth-Control Fight Isn't Over, WALl St. J., Sept. 10, 2014, at A2.

41. See 45 C.F.R. $§ 147.131$ (2013).

42. A grandfathered plan is exempt from some, but not all, of the insurance market reforms enacted by the Patient Protection and Affordable Care. See Patient Protection and Affordable Care Act, Pub. L. No. 111-148, Title I, Title X, §§ 1251, 10103(d), 124 Stat. 161,895 (codified at 42 U.S.C. $\S 18011(2010)$ ). A grandfathered plan is any group health plan that was in existence as of March 23, 2010, that, among other requirements, does not eliminate any benefits, substantially increase cost-sharing requirements, substantially reduce employer contributions toward coverage, nor impose certain new or modified annual limits on benefits after March 23, 2010. See generally 29 C.F.R. § 2590.715-1251 (2010); 45 C.F.R. § 147.140(g) (2010); Temp. Treas. Reg. § 54.9815$1251 \mathrm{~T}(2010)$.

43. Equal Employment Opportunity Commission Enforcement Guidance Commission Decision on Coverage of Contraception (Dec. 14, 2000), available at http://www.eeoc.gov/ policy/docs/decision-contraception.html, archived at http://perma.cc/YX9K-9A29.

44. Arguably contraception is not a medical treatment related to pregnancy but a treatment to prevent pregnancy, and therefore, it is not covered by the Pregnancy Discrimination Act amendments to Title VII. See, e.g., Standridge v. Union Pac. R.R. Co., 479 F.3d 936, 942 (8th Cir. 2007), reh'g and reh'g en banc denied, No. 06-1706 (8th Cir. May 23, 2007).

45. See Emp't Div. v. Smith, 494 U.S. 872, 883 (1990) (balancing governmental actions that substantially burden a religious practice must be justified by a compelling interest is not applicable across-the-board for all forms of conduct).

46. Shervert v. Verner, 374 U.S. 398 (1963).

47. Id. at 403-05. 
employed the least restrictive means in furtherance of a compelling state interest. ${ }^{48}$ In that case the Court held that a state could not deny unemployment benefits to an individual whose employment was terminated for her refusal to work on the Sabbath. ${ }^{49}$ Similarly, in Wisconsin v. Yoder, the Court held that a state could not compel attendance at school by Amish children in violation of the parents' religious beliefs. ${ }^{50}$ In Yoder, the Court made clear that the religious beliefs in question had to emanate from objective practices and not subjective interpretations of religious doctrine. ${ }^{51}$

Any nuance or subtlety derived from the equities of a particular case gave way in Employment Division v. Smith. ${ }^{52}$ In that case, the Court, upholding the denial of state unemployment benefits to two individuals who were terminated from employment because of their use of an illegal narcotic substance during a religious ceremony, held that the First Amendment does not require laws of general applicability to accommodate the religious beliefs of the citizenry. ${ }^{53}$ Congress, reacting to public displeasure with the Court, enacted the Religious Freedom Restoration Act of 1993 ("RFRA"). ${ }^{54}$ The legislation stated that one of the purposes of the statute was to restore the compelling interest test as set forth in Sherbert and Yoder. ${ }^{55}$

RFRA prohibits the federal government from imposing a substantial burden of a person's exercise of religion, even if such burden results from a law of general applicability, unless the government demonstrates that its imposition is in furtherance of a compelling government interest and that the imposition at issue is the least restrictive means of furthering that interest. ${ }^{56}$ All federal law is

48. Id. at 407 .

49. Id. at 404 .

50. Wisconsin v. Yoder, 406 U.S. 205, 234 (1972).

51. Id. at 215-16. Congress took exception to this requirement when it amended the Religious Freedom Restoration Act in 2000. See infra note 58.

52. Emp't Div. v. Smith, 494 U.S. 872 (1990).

53. Id. at 878-79. Three years after Smith, the Court unanimously held that several local ordinances prohibiting animal sacrifice that seemingly were of general applicability were, in fact, targeted at the Santeria faith. See Church of Lukumi Babalu Aye, Inc. v. Hialeah, 508 U.S. 520, 531-38 (1993). Accordingly, Smith was inapplicable and the ordinances failed to pass constitutional muster under strict scrutiny. Id.

54. Pub. L. No. 103-141, 107 Stat. 1488 (1993) (codified at 42 U.S.C. $\S \S 2000 b b-2000 b b-4)$.

55. 42 U.S.C. $\$ 2000 \mathrm{bb}-(\mathrm{b})(1)$ (2010).

56. Id. $\S 2000 \mathrm{bb}-1(\mathrm{~b})$. The statute is not intended to affect the application of the Establishment Clause of the First Amendment. Id. $\S 2000 \mathrm{bb}-4$. For purposes of the statute, government means the United States, the District of Columbia, the Commonwealth of Puerto Rico, and each territory and possession of the United States. Id. $\S \S 2000 \mathrm{bb}-2(1)-(2)$. The statute, as originally enacted, also applied to the states and their political subdivisions. See Religious Freedom Restoration Act of 1993, Pub. L. 103-141, § 5(1), 107 Stat. 1489 (1993). The statute was amended to read in its current form by the Religious Land Use and Institutionalized Persons Act of 2000 ("RLUIPA"), Pub. L. No. 106-274, § 7 (a)(1), 114 Stat. 803, 806 (2000). This legislation was enacted in response to the Court's decision in City of Boerne v. Flores, 521 U.S. 507 (1997). In 
subject to RFRA except for statutes that were adopted after November 16, 1993, and explicitly excluded themselves from its strictures by reference to RFRA. ${ }^{57}$ Under the statute, the exercise of religion is defined as any exercise of religion, whether or not compelled by, or central to, a system of religious belief. ${ }^{58}$

\section{BURWELL V. HOBBY LOBBY STORES, INC.}

\section{A. Factual Background}

Conestoga Wood Specialties Corp. is a fifty year old for-profit corporation organized under the laws of Pennsylvania that employs 950 people. ${ }^{59}$ The corporation's voting stock is held entirely by the founder, his wife, and three sons, all of whom are devout Mennonites. ${ }^{60}$ The Mennonite Church opposes abortion, and the shareholders operate the corporation in accordance with their religious principles. ${ }^{61}$ The corporation objected to two of the drugs for which coverage was mandated under the administrative guidelines implementing the requirements of the Patient Protections and Affordable Care Act because it believed that such drugs were abortifacients. ${ }^{62}$ Consequently, the provision of insurance coverage for the purchase of such drugs violates its religious beliefs. ${ }^{63}$ The Third Circuit, affirming the district court's denial of injunctive relief, rejected the corporation's claims that the contraception mandate violated RFRA and the First Amendment because, in the court's opinion, a for-profit secular corporation cannot engage in religious exercise and is therefore protected neither under RFRA nor the First Amendment. ${ }^{64}$ The court also rejected similar claims brought by the

that case, the Court held that RFRA as applied to the states exceeded Congress' authority to enforce the Fourteenth Amendment. Id at 536. RLUIPA is aimed at projects that receive federal funding or affect interstate commerce, and therefore, derives its authority from Congress' spending and commerce powers. See 42 U.S.C. $\S 2000 c c(a)(2)$ (2010).

57. 42 U.S.C. $\S \S 2000 \mathrm{bb}-3(\mathrm{a})-(\mathrm{b})(2010)$.

58. Id. $\S \S 2000 \mathrm{bb}-2(4), 2000 \mathrm{cc}-5(7)$. As originally enacted, RFRA defined the exercise of religion as the exercise of religion under the First Amendment. See Religious Freedom Restoration Act of 1993, Pub. L. 103-141, § 5(4), 107 Stat. 1489 (1993). The statute was amended to read in its current form by RLUIPA, Pub. L. 106-274, § 7(a)(3), 114 Stat. 806 (2000). The majority placed significant emphasis on the subsequent change in this definition. See infra notes 100-01 and accompanying text.

59. See Conestoga Wood Specialties Corp. v. Sec'y of the U.S. Dep't of Health \& Human Servs., 724 F.3d 377, 381 (3d Cir. 2013), aff'g Conestoga Wood Specialties Corp. v. Sebelius, 917 F. Supp. 2d 394 (E.D. Pa. 2013).

60. Id. at 381-82.

61. Id. at $381-82 ; i d$. at 382 n.5.

62. Id. at 381-82.

63. Id.

64. Id. at 385-88. The court did not believe that Citizens United v. FEC, 558 U.S. 310 (2010), the controversial campaign finance case that held that corporations are entitled to the speech protections of the First Amendment, entitled corporations to the free exercise protections of the 
shareholders because the mandate was not imposed upon them personally. ${ }^{65}$

Hobby Lobby Stores, Inc. is a forty-five year old for-profit corporation organized under the laws of Oklahoma that employs approximately 13,000 people. ${ }^{66}$ Like Conestoga Wood Specialties Corp., this corporation is controlled and managed exclusively by the founder, his spouse, and his children. ${ }^{67}$ One of the founder's children also owns and operates an affiliated business, Mardel, Inc., that operates Christian bookstores and employs almost 400 people. ${ }^{68}$ This corporation is also a for-profit corporation organized under the laws of Oklahoma. Both corporations are operated according to their owners' Christian beliefs. ${ }^{69}$ Employees of Hobby Lobby Stores and Mardel are covered under the Hobby Lobby Stores' group health insurance plan, a self-insured plan that the corporation did not elect to grandfather under the Patient Protection and Affordable Care Act. ${ }^{70}$ The corporations raised objections to the contraception mandate similar to those asserted by Conestoga Wood Specialties Corp., except in this case the corporations objected to the provision of insurance coverage for the purchase of four of the drugs for which coverage was mandated. ${ }^{71}$

After the district court denied the corporations injunctive relief, the Tenth Circuit held that the two corporations were persons for both First Amendment and RFRA purposes. ${ }^{72}$ With respect to the First Amendment, the court, contrary to the Third Circuit's opinion, held that "the Free Exercise Clause is not a 'purely personal' guarantee . . . limited to the protection of individuals." 73 Instead, its protection extends to corporations derivatively through the constitutional right to associate. $^{74}$ The court also held that corporations are persons for purposes of

First Amendment. In the court's opinion, certain constitutional protections are "“purely personal'. . . because 'the historic function' of the particular guarantee has been limited to the protection of individuals." Conestoga, 724 F.3d at 383 (quoting First Nat'1 Bank of Boston v. Belotti, 435 U.S. 765, 778 n.14 (1978)).

65. Conestoga, 724 F.3d at 388-89.

66. Hobby Lobby Stores, Inc. v. Sebelius, 723 F.3d 1114, 1122 (10th Cir. 2013), rev'g 870 F. Supp.2d 1278 (W.D. Okla. 2012).

67. Id. The corporations actually were controlled by a trust. The court did not make clear whether all of the stock of the corporations was held in trust or whether the trust beneficiaries extended beyond the founder, his spouse, and children.

68. Id.

69. Id. at 1120. The Green family, the family that controls Hobby Lobby Stores and Mardel, is planning to establish a Bible museum in Washington, D.C. and its plans have raised concerns that the family's activities will extend to efforts to influence Congress. See Alan Rappeport, Family Behind Hobby Lobby Has New Project: Bible Museum, N.Y. TIMES, July 17, 2014, at A15.

70. Sebelius, 723 F.3d at 1124; see supra note 42 and accompanying text for a discussion of grandfathered status.

71. Sebelius, 723 F.3d at 1124-25.

72. Id. at 1128-29.

73. Id. at 1133-34 (quoting First Nat'l Bank of Boston v. Belotti, 435 U.S. 765, 778 n.14 (1978)) (emphasis in original).

74. Id. at 1133. 
RFRA on the basis of statutory interpretation. ${ }^{75}$ The court proceeded to determine that the contraception mandate violated RFRA because it substantially burdened the corporations' exercise of religion and that the Department of Health and Human Services demonstrated neither a compelling interest in enforcing the mandate against the corporations nor that the mandate was the least restrictive means in furthering the government's asserted interests. ${ }^{76}$

\section{B. United States Supreme Court Decision}

The Court, in a 5-4 ruling, held that for-profit corporations are persons for purposes of RFRA and that the contraception mandate violated RFRA. ${ }^{77}$ Justice Alito, writing for the majority, asserted that, in enacting RFRA, Congress intended to provide protections for religious liberty far beyond the required constitutional protections under pre-Smith case law. ${ }^{78}$ Accordingly, it is unlikely that RFRA would require small business owners to choose between incorporation and religious protections. The Court held that corporations are persons for RFRA purposes, that the contraception mandate imposed a substantial burden on its free exercise rights, and that the government could have achieved its asserted compelling purpose by less restrictive means. ${ }^{79}$

1. Corporate Personhood.-The Court held that for-profit corporations are included within the statutory definition of persons for several reasons. ${ }^{80}$ First, the Court examined the Dictionary Act's definition of the term "person" and, according to the majority, the statutory definition included corporations as well

75. Id. at 1129-30.

76. Id. at 1137-45. Although the court held that a for-profit corporation enjoys free exercise protection under the First Amendment, it did not opine on whether the contraception mandate violated the First Amendment. It is unlikely that the contraception mandate would be found to violate the test set forth in Employment Division v. Smith. See supra notes 52-53 and accompanying text. However, the dissent in Conestoga Wood Specialties Corp. believed that the contraception mandate, due to its myriad exceptions, was not a law of general applicability, and consequently, there is reasonable likelihood that it does not pass constitutional muster. See Conestoga Wood Specialties Corp. v. Sec'y of the U.S. Dep't of Health \& Human Servs., 724 F.3d at 415-16 (Jordan, J., dissenting).

77. Justice Alito delivered the opinion of the Court and was joined by Chief Justice Roberts and Justices Scalia, Kennedy, and Thomas. Justice Kennedy also filed a concurring opinion. Justice Ginsburg filed a dissenting opinion in which Justice Sotomayor joined and in which Justices Breyer and Kagan joined in part. Justices Kagan and Breyer filed a separate dissenting opinion in which they indicated that it was not necessary to decide in this case whether for-profit corporations or their owners could make a claim under RFRA. See Burwell v. Hobby Lobby Stores, Inc., 134 S. Ct. 2751 (2014).

78. Id. at 2760-61 (majority opinion).

79. Id. at 2759-61.

80. Id. at 2759-60. Justices Ginsburg and Sotomayor were the only Justices who dissented from this holding. Justices Breyer and Kagan dissented from the holding on the merits but believed it was not necessary to decide this issue. See supra note 77. 
as other non-natural persons within its scope. ${ }^{81}$ The definitions set forth in the Dictionary Act determine the meaning of any act of Congress unless the context indicates otherwise and nothing in RFRA appears to so indicate. ${ }^{82}$ Moreover, the fact, conceded by the Department of Health and Human Services, that non-profit corporations are persons within the meaning of the statute "effectively dispatches any argument that the term 'person' as used in RFRA does not reach the closely held corporations involved in these cases." 83 The term "persons" may encompass artificial entities or be limited to natural persons, "[b]ut no conceivable definition of the term include[ed] natural persons and nonprofit corporations, but not forprofit corporations." $\$ 4$

Second, the Court dismissed the assertion that the corporations in question cannot engage in the exercise of religion and, therefore, are not subject to the statute's protection. According to Justice Alito, the fact that the statute protects non-profit corporations belies the notion that the corporate form, per se, denies the applicability of the statute. ${ }^{85}$ He proceeded to examine whether the profit motive was the linchpin for the inapplicability of the statute. ${ }^{86}$ Justice Alito found no principled distinction between offering religious protection to a sole proprietor engaged in for-profit activities, which the Court had done, and a corporation engaged in similar activities. ${ }^{87}$ The notion that a for-profit corporation, in contrast to a sole proprietor, pursues profit making at the expense of all other objectives is belied both by modern corporate law and common business practices. $^{88}$ Both the laws of Pennsylvania and Oklahoma permit a for-profit corporation to engage in any lawful activity and pursue profits in accordance with the shareholders' religious beliefs. ${ }^{89}$ Moreover, many for-profit corporations are organized as such to avoid certain restrictions on lobbying and political activities to promote their religious or charitable goals. ${ }^{90}$

\section{Burwell, $134 \mathrm{~S}$. Ct. at 2768-70.}

82. Id. at 2769 (majority opinion).

83. Id.

84. Id. at 2756. Justice Ginsburg believed that the Senate's rejection of the so-called conscience amendment evidenced the intent by Congress to exclude for-profit corporations from the application of RFRA. See id. at 2789-90 (Ginsburg, J., dissenting). That amendment would have provided an exemption for employers who objected to coverage on religious or moral grounds. Id. The majority, in contrast, believed that the failure of the Senate to adopt such an amendment may simply have been due to the fact that the amendment would have allowed exemptions under far more circumstances than would be the case under RFRA. See id. at 2775 n.30 (majority opinion).

85. Id. at 2769 .

86. Id. at $2770-72,2770$ n.23.

87. Id. at $2769-70$.

88. Id. at $2770-71$.

89. Id. at 2771-72.

90. Id. at 2770-71. There are several types of tax exempt non-profit entities that derive their name from the applicable Internal Revenue Code section that defines them. For example, section 501(c)(3) organizations are organizations operated exclusively for religious, charitable, scientific, 
Justice Ginsburg rebutted the aforementioned contentions. ${ }^{91}$ Contrary to the majority's opinion, the context of RFRA does indicate that the term person is not meant to encompass for-profit corporations. ${ }^{92}$ The fact that the Court had never recognized a for-profit corporation's right to free exercise is quite expected because corporations "have no consciences, no beliefs, no feelings, no thoughts, no desires." ${ }^{\prime 93}$ The protections frequently afforded religious-based organizations reflect government solicitousness toward organizations that further individual religious freedoms and whose very existence is designed to further such freedoms. ${ }^{94}$ No such solicitude is given to, nor warranted for, for-profit corporations. ${ }^{95}$ Moreover, Justice Ginsburg asserted a principled rationale for the distinction between the religious accommodation that is properly afforded to individuals operating for-profit enterprises as proprietors and the accommodation that is properly afforded to such individuals operating the same enterprises in corporate form. ${ }^{96}$ Individuals who avail themselves of the corporate form separate themselves from the entity to obtain legal protection from personal

testing for public safety, literary, educational, to foster certain amateur sports, or to prevent cruelty to children or animals. I.R.C. $\S 501$ (c)(3) (2014). Contributions to section 501(c)(3) organizations, with the exception of those organized to test for public safety, are tax deductible by the donors. See id. $\S 170(\mathrm{c})(2)$. Section 501(c)(4) organizations are operated exclusively for the promotion of social welfare. Other tax-exempt entities include labor unions, business leagues, social clubs, domestic fraternal societies, benevolent life insurance associations, certain cooperatives, and employee benefit trusts. See generally id. $\S 501(\mathrm{c})$. There are significant differences among the organizations with respect to permissible political activity and disclosure. Section 501(c)(3) organizations are prohibited from participating or intervening in any political campaign, but they may engage in lobbying activity if such activities are not a substantial part of the entity's activities or if such activities are conducted through affiliated section 501(c)(4) organizations. See generally id. $\S 501(\mathrm{c})(3)$; Treas. Reg. $\S$ 1.501(c)(3)-1(c)(3)(i)-(iii), 1.501(c)(3)-1(e) (2008); Regan v. Taxation with Representation of Wash., 461 U.S. 540, 544 n.6 (1983). Thus, these organizations are not significant actors in electoral politics - at least not directly. In contrast, section 501(c)(4) organizations may engage in unlimited lobbying activities that are related to their exempt purpose and may also engage in political campaigns provided that such activity does not constitute the organization's primary activity. Treas. Reg. § 1.501(c)(4)-1(a)(2)(i) (1990) (emphasis added). Direct or indirect participation in political campaigns are not deemed activities that promote social welfare. Id. $\S 1.501(\mathrm{c})(4)-1(\mathrm{a})(2)(\mathrm{ii})$. Several section 501(c)(4) organizations, such as the American Association of Retired Persons and the National Rifle Association, are well known for their lobbying prowess and wield considerable political influence.

91. Burwell, 134 S. Ct. at 2793, 2794 n.12 (Ginsburg, J., dissenting).

92. Id. at 2793.

93. Id. at 2794 (Ginsburg, J., dissenting) (quoting Citizens United v. FEC, 558 U.S. 310, 466 (2010) (Stevens, J. dissenting in part and concurring in part)). The majority interpreted the lack of such cases in a much different light. See infra note 104 and accompanying text.

94. Burwell, 134 S. Ct. at 2794.

95. Id.

96. Id. at 2796-97 (Ginsburg, J., dissenting). 
liability. ${ }^{97}$

Third, the Court accepted neither the notion that RFRA merely codified the Court's pre-Smith jurisprudence nor the assertion that such jurisprudence denied that a for-profit corporation had rights to the free exercise of religion. ${ }^{98}$ Justice Alito believed that the statute did not restore the legal landscape to the status quo ante. ${ }^{99}$ The language of the statute, as originally enacted, referred to freedom of religious exercise under the First Amendment and not to freedom of religious exercise under existing Court precedent. ${ }^{100}$ In any event, later amendments to the statute resolved any ambiguity that may have existed in this respect. ${ }^{101}$ Justice Ginsburg's dissent disagreed with this interpretation of congressional intent. ${ }^{102}$ Referencing the express language of the statute, case law, and legislative history, she believed that RFRA was enacted to restore, by statute, the religious protections that the Court curtailed in Smith but nothing more. ${ }^{103}$ According to Justice Alito, a concession that RFRA incorporated pre-Smith law into the statute is not a concession of the point at issue because pre-Smith law implicitly recognized the standing of for-profit corporations to assert a free exercise claim. ${ }^{104}$ Referring to Title VII of the Civil Rights Act and an anti-discrimination statute relating to abortion, the Court stated that Congress has shown that it is capable of specificity when it wants to exclude for-profit corporations from the benefits of religious accommodation. ${ }^{105}$

Finally, Justice Alito dismissed the notion that the practical difficulties of applying RFRA to for-profit corporations are evidence of the congressional intent to exclude them from the application of the statute. ${ }^{106}$ There is little or no

97. Id. at 2797.

98. Id. at 2772 .

99. Id. at 2773 .

100. Id. at 2772 .

101. Id.; see supra notes 56, 58 and accompanying text for a discussion of the amendments enacted by RLUIPA in 2000.

102. Burwell, 134 S. Ct. at 2796-97 (Ginsburg, J., dissenting).

103. Id. at 2791-92. Justice Ginsburg stated that the Court's assertion in City of Boerne, that the statute's least restrictive means test went beyond pre-Smith requirements, was erroneous. See id. at 2792-93, 2793 n.11 The majority noted that Justice Ginsburg joined in that opinion. See id. at $2767 \mathrm{n} .18$ (majority opinion).

104. Id. at 2772-73. The Court cited to Gallagher v. Crown Kosher Super Market of Massachusetts, Inc., 366 U.S. 617 (1961). In that case, a corporation challenged a state law that required it to close its store on Sundays. The Court issued no holding on this issue, but two concurring Justices and three dissenting Justices did not question the standing of the corporation to bring the claim thereby implicitly endorsing its standing to bring a free exercise claim. Burwell, $134 \mathrm{~S}$. Ct. at 2773 . The Court also stated, in rebuttal to the dissent, that the fact that no such person brought a claim pre-Smith does not preclude such persons from bringing forth a claim at present. In effect, the fact that the Court had never explicitly sanctioned such a claim is not to be equated with the fact that it would not. See id.; see also supra note 93 and accompanying text.

105. Burwell, $134 \mathrm{~S}$. Ct. at 2773-74.

106. Id. at 2774. 
difficulty in determining the sincerity of a corporation's religious beliefs with respect to the corporations in this case. Closely held corporations controlled by one family, whose sincerity of belief is undisputed, pose no practical difficulties. ${ }^{107}$ Corporations with large number of diffuse shareholders have never brought a claim under RFRA and are unlikely to do so. ${ }^{108}$ Moreover, in the event that situations arise in which the sincerity of asserted religious beliefs is in doubt, Congress has expressed confidence that the courts are capable of sorting out legitimate claims from illegitimate claims. ${ }^{109}$ RLUIPA extended religious protections to prisoners, a class of claimants with a propensity for insincerity. ${ }^{110}$ The Court also was not troubled by the possibility of shareholder disputes regarding the conduct of a corporation's business. ${ }^{111}$ Such disputes, not unique to religious issues, are routine and are dispensed with by state corporate law. ${ }^{112}$ As expected, Justice Ginsburg envisions the majority's holding as the commencement of a ride down a slippery slope. ${ }^{113}$

Echoing to an extent its reasoning in Citizens United, the majority's view that Congress intended to extend religious protections to corporations was premised on the associational rights of individuals. ${ }^{114}$

Congress provided protection for people like the Hahns and Greens by employing a familiar legal fiction: It included corporations within RFRA's definition of "persons." But it is important to keep in mind that the purpose of this fiction is to provide protection for human beings. A corporation is simply a form of organization used by human beings to achieve desired ends. An established body of law specifies the rights and obligations of the people (including shareholders, officers, and employees) who are associated with a corporation in one way or another. When rights, whether constitutional or statutory, are extended to corporations, the purpose is to protect the rights of these people. For example, extending Fourth Amendment protection to corporations protects the privacy interests of employees and others associated with the company. Protecting corporations from government seizure of their property without just compensation protects all those who have a stake in the corporations' financial well-being. And protecting the freeexercise rights of corporations like Hobby Lobby, Conestoga, and

107. $I d$.

108. Id.

109. Id.

110. Id. RLUIPA was enacted, in part, to protect prisoners. It also was enacted to protect religious freedom from action by states and their instrumentalities after the Court held that RFRA was unconstitutional as applied to the states and their instrumentalities. See supra note 56 and accompanying text.

111. Burwell, 134 S. Ct. at 2774.

112. Id. at $2774-75$.

113. Id. at 2802-03 (Ginsburg, J. dissenting).

114. Id. at 2768 . 
Mardel protects the religious liberty of the humans who own and control those companies. ... Corporations, "separate and apart from" the human beings who own, run, and are employed by them, cannot do anything at all. ${ }^{115}$

2. Substantial Burden.-Having concluded that RFRA is indeed applicable to the corporations in this case, the Court proceeded to test the contraception mandate against the strictures of the statute. ${ }^{116}$ There was no dispute regarding the sincerity of the beliefs of the shareholders of all three corporations. ${ }^{117}$ The factual record made clear that the corporations were operated in accordance with the shareholders' religious tenets. ${ }^{118}$ Accordingly, the Court examined whether the contraception mandate substantially burdened the free exercise rights of the corporations and their shareholders. ${ }^{119}$

In order to operate their businesses according to conscience, the mandate presented the corporations with two choices. ${ }^{120}$ First, they could continue to offer health insurance coverage but exclude coverage for the contraceptives that they found morally objectionable. ${ }^{121}$ This choice would trigger the excise tax under Internal Revenue Code section $4980 \mathrm{D}$ - estimated by the Court to be $\$ 475$ million, \$33 million, and \$15 million per year for Hobby Lobby Stores, Conestoga Wood Specialties, and Mardel, respectively. ${ }^{122}$ Alternatively, the corporations could discontinue its health insurance coverage for their employees. ${ }^{123}$ However, if one employee qualified for a subsidy or tax credit for the purchase of insurance on a government exchange then the employer mandate penalty imposed by Internal Revenue Code section $4890 \mathrm{H}$ would be triggered. ${ }^{124}$ The Court estimated that this penalty could amount to \$26 million, \$1.8 million, and $\$ 800,000$ for Hobby Lobby Stores, Conestoga Wood Specialties, and Mardel, respectively. ${ }^{125}$

The Court, for procedural reasons, stated that it would not address the government's contention that the burden imposed by the mandate was not substantial because the penalty imposed by Internal Revenue Code section $4980 \mathrm{H}$

115. Id.

116. Id. at 2775 .

117. Id. at 2774 .

118. See id. at 2764-66. The corporations adopted mission statements and other formal statements that reflected their religious beliefs. Furthermore, Hobby Lobby Stores, Inc. and Mardel, Inc. closed their stores on Sundays to their financial detriment.

119. Id. at 2774 .

120. Id. at 2775 .

121. Id.

122. Id. at 2775-76; see supra note 17 and accompanying text for a discussion of I.R.C. $\S$ 4980D (2014).

123. Burwell, 134 S. Ct. at 2776.

124. Id.

125. Id.; see supra notes 9-16 and accompanying text for a discussion of I.R.C. $\S 4980 \mathrm{H}$ (2014). 
would cost the companies less than the cost of the insurance coverage. ${ }^{126}$ However, the Court proceeded to state that it would find such an argument unpersuasive for several reasons. ${ }^{127}$ First, the provision of health insurance to their employees is motivated, in large part, by the religious beliefs of the three corporations and their shareholders. ${ }^{128}$ Moreover, the Court was unconvinced by the economics underlying this argument. ${ }^{129}$ A straight comparison of the cost of the penalty to the cost of insurance coverage fails to consider the fact that wages would be adjusted to compensate for the loss of health insurance benefits, that the penalty itself, unlike the insurance costs, is not tax deductible, and that the value of group health insurance coverage, unlike wages, is tax-free to the employees. ${ }^{130}$

The majority refused to countenance the government's assertion that the connection between the provision of insurance for objectionable drugs or products and the results produced from the use of such drugs or products is too attenuated to result in a substantial burden on free exercise rights. ${ }^{131}$ The morally objectionable result is the destruction of an embryo and this result can only occur by the intervening act of an employee who chooses to take advantage of the coverage to use one of the drugs or products in question. ${ }^{132}$ The Court noted that this argument is inconsistent with the provision of exemptions for religious employers. ${ }^{133}$ More importantly, the question of whether it is morally wrong to engage in an innocent act that nonetheless enables or facilitates an immoral act by another is, according to the Court, a moral and philosophical one that the Court — or any court — has no business addressing. ${ }^{134}$ When a person has drawn a line that morally he cannot cross, "it is not for us to say that the line he drew was an unreasonable one."'135

126. Burwell, $134 \mathrm{~S}$. Ct. at 2776.

127. Id.

128. Id.

129. Id at $2776-77$.

130. Id. The penalty imposed by I.R.C. $\S 4980 \mathrm{H}$ is not deductible. See I.R.C. $\S \S 275(\mathrm{a})(6)$, $4980 \mathrm{H}(\mathrm{c})(7)$ (2014). Employer provided health insurance is not taxable to the employees. See generally id. $\S \S 105-06$. As a result, in order to place the employees in the same after-tax position, the substitution of wages for such benefits will necessitate the employer to increase wages to account for the taxes due on such wages. Moreover, the achievement of a tax neutral result for all employees would be practically impossible because each employee's insurance costs would vary based on her particular circumstances. In addition, any cost advantages that group health insurance enjoys over individual insurance policies would be lost.

131. Burwell, 134 S. Ct. at 2777.

132. Id. at 2778 .

133. Id. at 2777 n.33.

134. Id. at 2778 .

135. Id. (quoting Thomas v. Review Bd. of Ind. Emp't Sec. Div., 450 U.S. 707, 715 (1981)). The Court distinguished the facts in this case from the facts in Tilton v. Richardson, 403 U.S. 672 (1971) and Board of Education of Central School District No. 1 v. Allen, 392 U.S. 236 (1968). In those cases, the Court rejected the assertion that the use of general tax revenues to subsidize the secular activities of religious institutions violated the Free Exercise Clause. Id. at 2779. However, 
Although admitting that the parties' beliefs are sincere, Justice Ginsburg did not believe that assertions regarding the substantiality of imposed burdens on religious exercise must go unchallenged. ${ }^{136}$ She placed significant importance on the fact that the adjective "substantial" was added to the statute after the original draft of the statute was proposed and that the Court's own precedents belie the notion that such inquiries are beyond the purview of judicial inquiry. ${ }^{137}$ For Justice Ginsburg, the intervening acts of employees and physicians make any religious burden visited upon the sponsors of the group health insurance coverage too attenuated to be considered substantial. ${ }^{138}$

3. Least Restrictive Means.- - Having determined that the substantial burden test was met, the Court assumed that the inclusion of the disputed forms of contraception in the mandate advances a compelling government interest. ${ }^{139}$ Accordingly, the majority proceeded to test the mandate against the statute's least restrictive means standard - a standard that, according to the Court, "is exceptionally demanding." 140 RFRA imposes the burden of proof upon the government to establish that the substantial burden it has placed upon a person is the least restrictive means of furthering a compelling government interest. ${ }^{141}$

The Court identified two methods that would further the government's interest of providing cost-free access to contraception in a less restrictive manner than the imposition of an employer coverage mandate. ${ }^{142}$ First, the government could assume the cost of providing the contraceptives at issue. ${ }^{143}$ The Department of Health \& Human Services failed to provide any cost estimates in this respect and the majority speculated that this cost would be trivial in comparison to the Patient Protection and Affordable Care Act's estimated \$1.3 trillion cost to the federal government over the next decade. ${ }^{144}$ The Court rejected the government's contention that RFRA cannot be employed to require the creation of entirely new programs. ${ }^{145}$ It refused to get bogged down in drawing distinctions between the creation of an entirely new program and the modification of an existing

the challenges in those cases were not based on the religious beliefs of the challengers but instead on their views of proper church-state relations. Id. at 2779.

136. Id. at 2798 .

137. See id. at 2799 (Ginsburg, J. dissenting) (citing Bowen v. Roy, 476 U.S. 693 (1986) (rejecting a free exercise claim that challenged the requirement to provide a social security number to a government agency); Hernandez v. Comm'r, 490 U.S. 680 (1989) (drawing a distinction between the sincerity of a belief and the substantiality of any burden imposed on such belief)).

138. Id.

139. Id. at 2780. The Court made this assumption, but it appeared to have made it somewhat grudgingly. The existence of various exemptions, particularly the exemption for grandfathered plans, appeared to trouble the Court in this respect.

140. $I d$.

141. Id. (citing 42 U.S.C. $\S 2000 b b-1(a)-(b)(2014))$.

142. Id. at $2780-81$.

143. Id. at 2780 .

144. Id. at $2780-81$.

145. Id. at 2781 . 
program. ${ }^{146}$ According to the Court, there was no need to draw such distinctions because nothing in RFRA precludes the possibility that a new program may be considered a less restrictive means to achieve an objective. ${ }^{147}$

More importantly, the accommodation that the government instituted for religious-based employers was a ready-made less restrictive alternative to the mandate. ${ }^{148}$ Regulations put in place a system under which a qualifying organization could certify to its insurance carrier or third-party administrator that it objected to the provision of coverage for certain contraceptives. ${ }^{149}$ The insurer or third-party administrator would then be obligated to provide coverage for these contraceptives without the imposition of any cost-sharing on the employer, the plan, the participants, or their beneficiaries. ${ }^{150}$ By the Court's own admission, this approach may not satisfy all religious objections to contraception coverage, but it would satisfy the objections of the complaining corporations in this case. ${ }^{151}$

The dissent disagreed that the "government pays" model is a viable alternative for two reasons. ${ }^{152}$ First, such a scheme would require the women seeking coverage to navigate the administrative procedures that such a scheme would no doubt entail - a burden that the majority noted pointedly would be negligible and preferable to no coverage at all. ${ }^{153}$ Moreover, the majority's cavalier resort to the government as the fallback paymaster for programs that forprofit entities find objectionable on religious grounds has no logical limit. ${ }^{154}$ If this approach is used to defeat the contraception mandate then it can also be used to defeat a host of other government imposed requirements such as minimum wage laws, anti-discrimination laws, and mandated coverage for drugs that have no reproductive implications. ${ }^{155}$ The majority made clear that its decision is about contraception coverage that is required to be provided by these particular

146. $I d$.

147. Id.

148. Id. at 2782 .

149. Id.

150. Id.; see supra note 40 and accompanying text for a discussion of this accommodation.

151. Burwell, 134 S. Ct. at 2782, 2782 n.30. In fact, the religious objections of some employers that are eligible to take advantage of this provision are not assuaged. See supra note 40, infra note 160 and accompanying text. The administration has not issued regulations or provided other guidance for plan sponsors or plan participants whose group health insurance plans, as a result of the Court's decision, do not cover all mandated forms of contraception. The Departments of Labor, Health and Human Services, and the Treasury issued a joint pronouncement which employers that chose to drop coverage of some forms of contraception must provide notice to participants pursuant to a pre-existing statute and Department of Labor regulations. See Dep't of Labor, FAQs About Affordable Care Act Implementation (Part XX), U.S. DEP'T OF LABOR (July 17, 2014), available at http://www.dol.gov/ebsa/faqs/faq-aca20.html, archived at http://perma.cc/3X7H-ZY9A.

152. Burwell, $134 \mathrm{~S}$. Ct. at 2801-03.

153. Id. at 2802 (Ginsburg, J. dissenting); id. at 2782-83.

154. Id. at 2802 (Ginsburg, J. dissenting).

155. Id. 
employers. ${ }^{156}$ Cases involving other issues or other drugs may very well have different outcomes depending on the particular facts and issues at stake. ${ }^{157}$

Justice Ginsburg appeared to be at a loss to posit any practical objections to the extension of the religious accommodation made for religious-based employers to for-profit employers. ${ }^{158}$ Instead, her objection was based on the fact that this accommodation may not satisfy religious objectors. ${ }^{159}$ Justice Ginsburg's trepidation in this regard very well may be warranted. The Court subsequently ordered a preliminary injunction barring the enforcement of the very accommodation that the majority believed was a practical alternative to the mandate against a religious college. ${ }^{160}$ Finally, Justice Ginsburg invoked the language of United States v. Lee to assert that the voluntary participation in the world of commerce comes with the obligation to subjugate one's religious and moral beliefs to the laws applicable to society as a whole. ${ }^{161}$ As the majority retorted, this is precisely what RFRA was enacted to avoid. ${ }^{162}$

\section{CRITIQue}

It was inevitable that the RFRA would meet the Patient Protection and Affordable Care Act. ${ }^{163}$ The former is a bad law, and the latter is a consequence of a flawed system of delivering health care insurance coverage. Justice Scalia forcefully articulated the rationale for the Court's holding in Employment Division v. Smith, the case that precipitated the enactment of RFRA. ${ }^{164}$

Conscientious scruples have not, in the course of the long struggle for

156. Id. at 2783 .

157. Id.

158. Id. at $2782-83$.

159. Id. at 2803. In addition, implementing the majority's suggestion may not be as seamless a process as the majority believed. See, e.g., Jess Bravin, High Court Spars on Birth-Control Coverage, WALl ST. J., July 5, 2014, at A4; Robert Pear \& Adam Liptak, Obama Weighs Steps to Cover Contraception, N.Y. TIMES, July 5, 2014 at A1.

160. Wheaton Coll. v. Burwell, No. 13A1284, 2014 U.S. LEXIS 4706 (July 3, 2014) (order granting preliminary injunction). The Obama Administration has indicated that it will issue regulations that will modify the accommodation procedures applicable to religious non-profit institutions to perhaps provide such institutions the option of notifying the Department of Health and Human Services directly that they will not provide contraception coverage. See Louise Radnofsky, Part of Contraception Rule to be Revised, WALl ST. J., July 23, 2014, at A5. New regulations recently were issued that provide the alternative notification procedure described above. See Treas. Reg. § 54.9815-2713AT (2014).

161. Burwell, 134 S. Ct. at 2804 (Ginsburg, J. dissenting). In Lee, the Court held that the Free Exercise Clause does not require the government to provide an exemption from social security taxes for religious objectors. See United States v. Lee, 455 U.S. 252, 260 (1982).

162. Burwell, $134 \mathrm{~S}$. Ct. at 2784.

163. See generallyid. at 2760-64 (providing brief history of development of RFRA and Patient Protection and Affordable Care Act).

164. Emp't Div. v. Smith, 494 U.S. 872, 879 (1990). 
religious toleration, relieved the individual from obedience to a general law not aimed at the promotion or restriction of religious beliefs. The mere possession of religious convictions which contradict the relevant concerns of a political society does not relieve the citizen from the discharge of political responsibilities. ... We first had occasion to assert that principle in Reynolds v. United States, 98 U.S. 145 (1879), where we rejected the claim that criminal laws against polygamy could not be constitutionally applied to those whose religion commanded the practice. "Laws," we said, "are made for the government of actions, and while they cannot interfere with mere religious belief and opinions, they may with practices. . . . Can a man excuse his practices to the contrary because of his religious belief? To permit this would be to make the professed doctrines of religious belief superior to the law of the land, and in effect to permit every citizen to become a law unto himself."165

Although, in Hobby Lobby Stores, the Court did not address whether the contraception mandate violated the constitutional rights of the three corporations, it is highly unlikely that, under Smith, the mandate is violative of the Free Exercise Clause. ${ }^{166}$ Congress decided that the Smith standard was not sufficiently solicitous of religious beliefs. ${ }^{167}$ This author has no objection to the legislative branch subjecting its legislative enactments to religious accommodations. RFRA, however, was a lazy and politically expedient way to do so. The statute was a reaction to a case whose facts begged for religious accommodation. The accommodation sought in Smith was the permission to use peyote in a religious ceremony, an accommodation that would have had no impact on third parties and would not have necessitated any modifications to existing government programs. ${ }^{168}$

RFRA subjects all subsequently enacted federal statutes to its strictures unless Congress deigns to exempt such statutes from RFRA's requirements. ${ }^{169}$ RFRA provides neither context nor nuance. In effect, it was a vote for religious freedom in a vacuum. Such a vote carried little political cost. In the post-RFRA world, Congress must now affirmatively exempt its handiwork from RFRA. ${ }^{170}$ Politically, this generally will require a vote that will be seen by many as anti-

165. Id. (quoting Minersville Sch. Dist. Bd. of Ed. v. Gobitis, 310 U.S. 586, 594-595 (1940); Reynolds v. United States, 98 U.S. 145, 166-67 (1879)).

166. Justice Ginsburg did address this issue in her dissent, and she believed that the mandate posed no constitutional issue under Smith. See Burwell, 134 S. Ct. at 2790-2791 (Ginsburg, J. dissenting). However, Judge Jordan of the Third Circuit believed that Smith was inapplicable to the case because, due to its myriad exemptions, the Patient Protection and Affordable Care Act was not a law of general applicability. See Conestoga Wood Specialties Corp. v. Sec'y of the U.S. Dep't of Health \& Human Servs., 724 F.3d 377, 415-16 (3d Cir. 2013).

167. Burwell, 134 S. Ct. at 2761 (citing 42 U.S.C. $\S \S 2000 b b(a)(2), 2000(a)(4)(1993)$ ).

168. Emp't Div., 494 U.S. at 874.

169. See 42 U.S.C. $\S \S 2000 b b-3(a)-(b)(2000)$.

170. Id. 
religion. ${ }^{171}$ The statute poses little practical difficulty when relief of a religious burden requires no more than an exemption to an existing government requirement. However, many government impositions on one party have been put in place to protect interests of third parties that are deemed sufficiently important to justify such an imposition. In such cases, an exemption requires the government to either set aside third party interests or enact modifications to existing programs to ameliorate the effects of the exemption. The Smith Court gave no constitutional succor to religious interests. ${ }^{172}$ However, there is a continuum of religious protection between Smith and the overly protective standard set forth in RFRA. Title VII achieves a balance between the religious interests of employees and the non-religious interests of employers in a practical manner by requiring employers to make reasonable accommodations. ${ }^{173}$ By requiring the use of least restrictive means to achieve objectives, RFRA slights the interests of third party beneficiaries of government actions.

Congress could have considered the effect of the Smith decision on a case-bycase basis and chosen to provide the protections provided by RFRA in a particular statute. This approach is fraught with political danger. It takes little imagination to envision the outcry that would have ensued had the Patient Protection and Affordable Care Act contained language similar to that contained in RFRA. Magically, a vote for religious freedom would be re-characterized as a vote against women. Critics are quick to denounce the Court's decision, yet the Court simply interpreted the language of a statute. ${ }^{174}$ If indeed the Court was misguided, Congress can amend the Patient Protection and Affordable Care Act to undo the Court's work. Even if one assumes the absence of the dysfunctional

171. A politician may be willing to accept this label if a sufficiently compelling political reason exists for doing so. Women's health is apparently a sufficient reason, given that a bill was introduced in the Senate that would exempt group health insurance mandates from the application of RFRA. See Protect Women's Health Care from Corporate Interference Act of 2014, S.2578, 113th Cong. $\S \S 3(19), 4(a)$-(b) (2014). The bill exempts religious organizations from its strictures, but it would, despite its name, apply to other employers, whether or not such employers are organized as corporations. It is unlikely that this proposed legislation will pass the Senate, let alone the Republican-controlled House of Representatives. See also Kristina Peterson, Democrats Fail in Move to Negate Hobby Lobby Ruling, WALL ST. J., July 17, 2014, at A4 (reporting that bill failed to obtain the sixty votes needed to advance).

172. Emp't Div., 494 U.S. at 907.

173. See, e.g., Redmond v. GAF Corp., 574 F.2d 897 (7th Cir. 1978); see 42 U.S.C. § 2000e(j) (2010) (accommodation is not reasonable if it requires more than a de minimis cost to implement); 42 U.S.C. § 2000e-2(a) (2010); 29 C.F.R. § 1605.2(e)(1) (2009); see also 29 C.F.R. § 1605.1 (2014); Welsh v. United States, 398 U.S. 333 (1970). See generally Zeke Katz, Note, Honor Thy Father and Thy Mother: Religious Accommodation Under Title VII in Adeyeye v. Heartland Sweeteners, LLC, 9 SEVENTH CIR. REV. 110 (2013), available at http://www.kentlaw.iit.edu/ Documents/Academic\%20Programs/7CR/v9-1/katz.pd, archived at http://perma.cc/4GBP-XQ6J.

174. See, e.g., Op-Ed, The Justices Endorse Imposing Religion on Employees, N.Y. TIMES, July 1, 2014, at A20; Dana Milbank, A Ruling for the People, at Least the "Artificial" Ones, WASH. Post, July 1, 2014, at A2. 
partisan gridlock that has enveloped Congress, such an enactment would carry significant political risk.

RFRA does not appear to have presented significant problems thus far because most federal actions do not implicate religious beliefs. However, a significant portion of health insurance is delivered to individuals through their employers. ${ }^{175}$ This system had its genesis as a mechanism to avoid wage controls during World War II and has been aided and abetted by income tax subsidies. ${ }^{176}$ Although group purchases of insurance yield certain efficiencies, the system has been subject to much criticism by economists because, among other things, it provides greater subsidies to higher income individuals; masks the true cost of coverage to the insured, resulting in the overconsumption of medical care; and distorts labor market mobility due to lack of portability. ${ }^{177}$

Until the enactment of the Patient Protection and Affordable Care Act, whether an employer offered coverage, and the scope of such coverage, was a choice made by the employer without government coercion. The legislation's individual mandate and employer mandate generated significant opposition because they made mandatory what was previously voluntary. ${ }^{178}$ The Patient Protection and Affordable Care Act went further, however, and dictated required

175. See Buchmueller \& Monheit, supra note 10.

176. Id. at 3 .

177. See id. at 8-14. The tax subsidy that results from tax-exempt income is dependent upon the marginal tax rates of the taxpayer who receives such income. The fact that the value of health insurance coverage is exempt from federal payroll taxes mitigates the tax advantage to high income employees because the income to which the Old-Age, Survivors, and Disability Insurance portion of payroll taxes applies is capped. See generally I.R.C. $\S \S 3101(a) ; 3121(a)(1)-(2)(2014)$. The portability issue has been addressed in part by the Consolidated Omnibus Budget Reconciliation Act of 1985 (“COBRA”), Pub. L. No. 99-272, 100 Stat. 82 (1986). Provisions of this statute mandate that employers with twenty or more full time equivalent employees offer medical coverage for a period of eighteen months to an employee or covered family member after a qualifying event. Among qualifying events are voluntary or involuntary termination of employment, divorce, death, and disability. For certain qualifying events, the coverage period is twenty-nine months or thirtysix months. The employee must pay for the cost of coverage, plus an allowable administrative fee. Failure to provide COBRA coverage subjects an employer to an excise tax. See generally I.R.C. $\S 4980$ (b) (2014). In addition, the Patient Protections and Affordable Care Act prohibits group health plans and insurers from excluding individuals from participation on account of pre-existing medical conditions or a history of illness. Patient Protection and Affordable Care Act, Pub. L. 111148, Title I, § 1201(3), (4) 124 Stat. 154, 156 (2010) (codified at 42 U.S.C. § 300gg-4 (2014)). Similarly, effective January 1, 2014, health issuers must accept every employer and individual who applies for coverage during open enrollment periods. Patient Protection and Affordable Care Act, Pub. L. 111-148, Title I, § 1201, 124 Stat. 156 (codified at 42 U.S.C. $§ \S 300 g g-1,300 g g-3$ (2014)). For a succinct discussion of the changes the Act made to the health insurance market, see Sarah Somers \& Jane Perkins, The Affordable Care Act: A Giant Step Toward Insurance Coverage for All Americans, 44 Clearinghouse ReV. 330 (2010).

178. See supra notes 27-35 and accompanying text. 
types of coverage, of which contraception services are but a piece. ${ }^{179}$ In effect, the federal government has intruded to an extraordinary degree into the details of individual health care - a highly personal matter - and has enlisted employers to assist it in its efforts. Consequently, the fact that RFRA has surfaced in this context should surprise no one.

Whether the Patient Protection and Affordable Care Act is sound policy and whether employer-based insurance coverage should retain its prominent place in the delivery of health insurance is well beyond the scope of this work. However, it should be evident to a casual observer that the mixture of an employer paymaster, employee health care decisions, and government fiat invites RFRA disputes.

The purpose of RFRA was to expand religious protections in the aftermath of Smith. ${ }^{180}$ However, the Court expanded these protections too far. Although certain rights may be held by both natural persons and institutions, the reasons why such rights are recognized in natural persons differ from the reasons that they are recognized in corporate solution. This difference justifies disparate treatment between a corporation and an individual with respect to certain rights. ${ }^{181}$ Moreover, justification of corporate rights by derivation from individual associational rights misunderstands the nature of the modern for-profit corporation. In addition, the Court interpreted the term "exercise" too broadly. RFRA protects the free exercise of religion but does not guarantee a clear conscience. ${ }^{182}$ If, in fact, RFRA does protect an expansive scope of activities, then some principled objective standard should be enlisted to determine whether the burden on free exercise imposed by a challenged action is indeed substantial. Finally, a narrow interpretation of exercise, objective limitations on substantiality, or both, will limit the occasions on which the courts engage RFRA's least restrictive means test-an engagement that has serious separation of powers implications.

179. Beginning in 2014, individual and small group market plans must provide coverage for ten statutory categories of "essential health benefits." See Patient Protection and Affordable Care Act Pub. L. 111-148, Title I, $\S \S 1201,1302,124$ Stat. 161, 163-64 (2010) (codified at 42 U.S.C. $\S \S 300$ gg-6, 18022 (2014)). Although employers with more than 100 employees are not required to cover all ten essential benefits, the Act requires large employer-insured plans and all self-insured plans to meet similar standards or be subject to the employer mandate set forth in I.R.C. $\S 49080$ H. See supra notes 29-35 and accompanying text. The contraception mandate is imposed by another provision of the statute and is applicable to all health plans except grandfathered plans and plans of certain religious-based organizations. See Patient Protection and Affordable Care Act, Pub. L. 111-148, §§ 1001, 1251, 124 Stat. 130-31, 161-62 (codified at 42 U.S.C. § 300gg-13, 18011 (2014)); see also supra notes 38-42 and accompanying text.

180. Burwell v. Hobby Lobby Stores, Inc., 134 S. Ct. 2751, 2761 (2014) (citing 42 U.S.C. $\S \S$ 2000bb(a)(2), 2000bb(a)(4) (1993)).

181. See id. at 2794-97 (Ginsburg, J. dissenting).

182. See id. at 2804 (Ginsburg, J. dissenting). 


\section{A. RFRA and Corporations}

The principle of regarding a corporation as a person, for legal purposes, has long been recognized by the Court. ${ }^{183}$ A corporation is a taxpaying entity, and it may be sued civilly and convicted criminally. ${ }^{184}$ Its property is protected against unreasonable searches and seizures, and its treasury is immune from the government's imposition of excessive fines. ${ }^{185}$ The separate legal status of the corporate form is uncontroversial in these respects because such status is premised on notions that sound in property law. ${ }^{186}$ However, certain rights - particularly those involving speech and religion-would appear, to a casual observer, to reside exclusively with natural persons. ${ }^{187}$ In Citizens United v. FEC, one of the Court's most controversial decisions in recent times, the Court held that a corporation is a person for purposes of First Amendment speech protections. ${ }^{188}$ Both the freedom to speak and the ability to freely exercise one's faith are fundamental rights and enjoy vigorous legal protection from government interference. ${ }^{189}$ However, there are significant differences between these two rights, and an examination of these differences justifies the disparate treatment of corporate entitlements to these rights.

Justice Alito placed great emphasis on the Dictionary Act's definition of a person. ${ }^{190}$ Moreover, the fact that certain religious-based corporations were either exempted from, or provided accommodations in order to comply with, the contraception mandate was a tacit admission that the corporations were indeed persons for purposes of RFRA. ${ }^{191}$ However, the Dictionary Act's provisions apply unless the context indicates otherwise. The issue of whether or not the

183. Corporate personhood, for purposes of due process and equal protection rights under the Fourteenth Amendment, was established as early as 1886. See Santa Clara Cnty. v. S. Pac. R.R., 118 U.S. 394 (1886).

184. For federal purposes and many state purposes, a corporation meeting the qualifications set forth in Subchapter S of the Internal Revenue Code is, in most cases, not subject to income tax. However, subchapter $\mathrm{S}$ is limited strictly to income taxes and has no effect on employment, excise, and other federal taxes, and does not affect state or local employment and property taxes. See generally I.R.C. $\S \S 1361-63$ (2014).

185. See, e.g., Browning-Ferris Indus. of Vt., Inc. v. Kelco Disposal, Inc., 492 U.S. 257, 280 (1989) (holding that punitive damages are not susceptible to an Eighth Amendment challenge but not intimating in any way that a corporation is not protected by the Eighth Amendment); Hale v. Henkel, 201 U.S. 43, 78-79 (1906) (holding that a corporation has Fourth Amendment protection against unreasonable searches and seizures).

186. See, e.g., Hale, 201 U.S. at 78-79 (holding that corporations may enjoy protection from government seizure of their property).

187. The right against self-incrimination does not apply to corporations. See id. at 69-70; see also infra note 262 and accompanying text.

188. Citizens United v. FEC, 558 U.S. 310, 361-62 (2010).

189. See U.S. CONST. amend. I.

190. Burwell v. Hobby Lobby Stores, Inc., 134 S. Ct. 2751, 2768-69 (2014).

191. See id. at 2763. 
context in a particular case indicated otherwise begs the questions of why the free exercise of religion is valued so dearly and whether this answer justifies its extension to for-profit corporations.

1. Free Exercise v. Free Expression.-Individual rights of expression and free exercise can be justified on utilitarian, or policy-based, grounds or on a more fundamental level. These rights have been identified as fundamental rights and, accordingly, state-imposed restrictions on such rights are subject to strict scrutiny. Why are such rights fundamental? A right can be deemed fundamental for no greater reason than the Kantian belief that such right is essential in order to accord human beings the respect that they deserve as such. ${ }^{192}$ The framers of the Constitution undoubtedly subscribed to this view, at least in certain respects, and it provides support for the existence of other constitutional rights, such as the right against cruel and unusual punishment and the right to be free from racial discrimination. ${ }^{193}$

Freedom of expression has Kantian roots, as noted implicitly by Justice Brandeis in Whitney v. California, when he stated that "[t]hose who won our independence believed that the final end of the State was to make men free to develop their faculties." 194 Freedom of speech is the natural extension of that quintessential human characteristic, the freedom of thought. ${ }^{195}$ Substantive due process claims to autonomy and other fundamental rights putatively have their genesis in the self-actualization aspect of free expression. ${ }^{196}$ In the landmark right to privacy case Griswold v. Connecticut, Justice Douglas believed that peripheral rights necessary to secure more basic rights - the freedom to read, to inquire, to teach, and to associate - emanate from the First Amendment. ${ }^{197}$ Justice Cardozo articulated somewhat similar justifications in support of freedom of speech and

192. Claire Andre \& Manuel Velasquez, Rights Stuff, SANTA Clara UnIVERSITY, http://www.scu.edu/ethics/publications/iie/v3n1/ (last visited Oct. 15, 2014), archived at http://perma.cc/D9XJ-NFDU.

193. See U.S. CONST. amend. VIII; U.S. Const. amend. XIV. Immanuel Kant's philosophy of rights is often referred to as a philosophy rooted in "natural rights" and the idea that human beings are entitled to certain rights simply by virtue of their status as free and autonomous beings capable of rational thought. A detailed discussion of Kant is well beyond the scope of this work. For an introduction to Kant's philosophy, see IMMANUEL KANT, BASIC WRITINGS OF KANT (Allen W. Wood ed., 2001). The Declaration of Independence speaks of certain inalienable rights that were conferred to individuals by their creator. THE DECLARATION OF INDEPENDENCE, para. 2 (U.S. 1776). Moreover, the Constitution was ratified, in part, in order to "secure the Blessings of Liberty." U.S. CONST. pmbl.

194. Whitney v. California, 274 U.S. 357, 375 (1927) (Brandeis, J., concurring).

195. Justice Holmes, defending the right of a pacifist to become a naturalized citizen, stated that "if there is any principle of the Constitution that more imperatively calls for attachment than any other it is the principle of free thought - not free thought for those who agree with us but freedom for the thought that we hate." United States v. Schwimmer, 279 U.S. 644, 654-55 (1929)

(Holmes, J., dissenting).

196. See Griswold v. Connecticut, 381 U.S. 479, 482-83 (1965).

197. Id. 
expression. ${ }^{198}$ Freedom to exercise one's faith is justifiable on similar grounds. It is a natural extension of freedom of thought and implicates rights of autonomy, inquiry, and association.

Alternatively, a right may be considered fundamental because its existence is essential to the well-being of the society. In contrast to the Kantian view, such rights are considered instrumental and are rooted in a utilitarian rationale. ${ }^{199}$ Despite the fact that, under both views, rights may be deemed fundamental, the protection we afford such rights may differ depending on whether they are natural rights or policy-based rights. Natural rights are immune from the traditional costbenefit type of analysis, but policy-based rights enjoy no such immunity. ${ }^{200}$ Of course, many rights can be supported on both grounds. For example, the exclusionary rule and the right to confront witnesses are supportable both by the notion that individuals are entitled to procedures that provide elemental fairness and by the fact that such practices foster a healthy respect for law enforcement and the criminal justice system. ${ }^{201}$ Free speech rights are similarly supported by both rationales. Two giants of First Amendment jurisprudence, Justices Holmes and Brandeis, often supported the right of free expression on utilitarian grounds. ${ }^{202}$

A corporation cannot have "natural rights." 203 Such rights, whether one believes they are derived by humans from a deity or that they simply attach to

198. See Palko v. Connecticut, 302 U.S. 319, 326-27 (1937) (stating that freedom of thought and speech is "the indispensable condition, of nearly every other form of freedom").

199. See Palko, 302 U.S. at 326-27.

200. See id. at 326-29 (discussing liberties and rights).

201. The exclusionary rule is a judicially developed doctrine that buttresses the Fourth Amendment protection against unreasonable searches and seizures by requiring that evidence obtained in such unreasonable searches and seizures be excluded from evidence at trial. See U.S. CONST. amend. IV; Mapp v. Ohio, 367 U.S. 643 (1961); see also U.S. CONST. amend. VI. A recent United States Supreme Court case illustrated the supporting of rights, despite the potential utilitarian consequences. In Melendez-Diaz v. Massachusetts, the Court held that the accused had the right to confront the affiant whose affidavit, regarding the results of forensic testing of a substance found to be cocaine, was admitted into evidence. Mendez-Diaz v. Massachusetts, 557 U.S. 305 (2009). Despite protestations by the government that such a requirement would create tremendous practical problems for law enforcement authorities, the Court held that the Sixth Amendment's Confrontation Clause mandated this result. Id.

202. "Those who won our independence ... valued liberty both as an end, and as a means. . . They believed that freedom to think as you will and speak as you think are means indispensable to the discovery and spread of political truth." Whitney v. California, 274 U.S. 357, 375 (1927) (Brandeis, J., concurring). Justice Holmes' famous dissent in Abrams v. United States put forth his position that society is best served by "free trade in ideas" and that truth is best tested in the "competition of the market." Abrams v. United States, 250 U.S. 616, 630 (1919) (Holmes, J., dissenting).

203. Liam Seamus O'Melinn, Neither Contract Nor Concession: The Public Personality of the Corporation, 74 GEO. WASH. L. REV. 201, 238 (2006) (quoting Case of Sutton's Hosp., 77 Eng. Rep. 960, 973 (K.B. 1612)). 
individuals by virtue of their humanity, cannot attach to a corporation. ${ }^{204}$ As Sir Edward Coke stated, corporations "have no souls." 205 The corporation is a utilitarian construct. ${ }^{206}$ Nobel Laureate R.H. Coase theorized that the reason firms existed at all was to serve as a mechanism to direct resources in a cost efficient manner. ${ }^{207}$

The corporate characteristics of unlimited life and limited liability were put in place to facilitate both long-term business endeavors and the deployment of capital to make such endeavors possible. ${ }^{208}$ Long ago, the Court recognized the instrumental nature of the corporate form. ${ }^{209}$ In Trustees of Dartmouth College v. Woodward, Chief Justice Marshall stated that corporate perpetual life makes possible "a perpetual succession of individuals" capable of acting for the promotion of a particular end, "like one immortal being." 210 Chief Justice Taney emphasized that corporations exist to benefit the public in Charles River Bridge v. Warren Bridge. ${ }^{211}$ Proponents of social responsibility posit that a corporation must take into account the interests of a diverse group of stakeholders such as employees, suppliers, and the community at large. ${ }^{212}$ Even the critics of corporate social responsibility recognize the corporation's utilitarian purpose because, for such critics, a corporation acts in a socially responsible manner and benefits society by producing goods and services that satisfy the needs or desires of its customers. ${ }^{213}$ The debate about corporate purpose is over how it meets its social obligation and not over whether it has such an obligation. Consequently, intrusions on corporate rights are justifiable on policy grounds.

Citizens United, ${ }^{214}$ in this author's opinion, was correctly decided. However, the reason this author believes that it was correctly decided has little to do with

204. Id.

205. Id. at 207.

206. See R.H. Coase, The Nature of the Firm, 4 ECONOMICA 386, 392 (1937).

207. Id.

208. See O'Melinn, supra note 203, at 232-33.

209. See Tr. of Dartmouth Coll. v. Woodward, 17 U.S. 518, 636 (1819).

210. Id.

211. See Charles River Bridge v. Warren Bridge, 36 U.S. 420, 548 (1837).

212. See, e.g., Edwin M. Epstein, The Good Company: Rhetoric or Reality? Corporate Social Responsibility and Business Ethics Redux, 44 Am. BuS. L.J. 207 (2007); David Hess, Social Reporting: A Reflexive Law Approach to Corporate Social Responsibility, 25 IOWA J. CORP. L. 41 (1999). Traditionally, boards of directors owed a fiduciary duty to shareholders only. See Janet E. Kerr, Sustainability Meets Profitability: The Convenient Truth of How the Business Judgment Rule Protects A Board's Decision to Engage in Social Entrepreneurship, 29 CARDOZO L. REV. 623, 637-38 (2007). However, courts, including the Delaware courts, have sanctioned the consideration by boards and management of outside stakeholder interests. $I d$. Moreover, a number of states have enacted "other constituency" statutes that permit officers and directors to consider the interests of various stakeholders when making decisions. Id.

213. See, e.g., Peter Koslowski, The Limits of Shareholder Value, 27 J. Bus. ETHICs 137, 138 (2000).

214. Citizens United v. FEC., 558 U.S. 310 (2010). 
corporate personhood and everything to do with the utility of speech, particularly political speech. From a utilitarian perspective, speech is fundamentally different than religion. The utility of speech is derived principally from its propensity to inform and agitate the citizenry, especially political speech. ${ }^{215}$

Speech is an essential mechanism of democracy, for it is the means to hold officials accountable to the people. . . . The right of citizens to inquire, to hear, to speak, and to use information to reach consensus is a precondition to enlightened self-government and a necessary means to protect it. ${ }^{216}$

Political speech has inherent social value that is not diminished because it originates from corporate lips.

The constitutional protection afforded commercial speech evidences utilitarian considerations. Commercial speech, defined as speech that does no more than propose a commercial transaction, has enjoyed constitutional protection at a lesser level than political speech for almost fifty years. ${ }^{217}$ Restrictions imposed upon commercial speech are not subject to exacting scrutiny but instead are examined under an intermediate standard. ${ }^{218}$ Moreover, it is the content of the speech, and not its motivation, that controls the classification of such speech. ${ }^{219}$

Neither a labor leader's exhortation to strike, nor an economist's dissertation on the money supply, should receive any lesser protection because the subject matter concerns only the economic interests of the audience. Nor should the economic motivation of the speaker qualify his constitutional protection; even Shakespeare may have been motivated by the prospect of pecuniary reward. ${ }^{220}$

In contrast, the free exercise of religion is firmly rooted in natural law justifications. $^{221}$ Admittedly, the exercise of religion has some utilitarian consequences. For example, free exercise that takes the form of aid for the poor, kindness to strangers, and other laudable behaviors has salutary effects on the public at large. ${ }^{222}$ However, this is not why we protect religious freedom. We

215. Id. at 339 .

216. Id.

217. See, e.g., Cent. Hudson Gas \& Elec. Corp. v. Pub. Serv. Comm'n, 447 U.S. 557, 562 (1980); Va. Pharmacy Bd. v. Va. Consumer Council, 425 U.S. 748, 760-61 (1976); Bigelow v. Virginia, 421 U.S. 809, 822 (1975).

218. Commercial speech restrictions must be supported by a substantial, as opposed to a compelling, government interest, and such restrictions must be proportional to that interest. See Cent. Hudson Gas \& Elec. Corp., 447 U.S. at 564.

219. See id.

220. Id. at 579-80 (Stevens, J., concurring).

221. See generally Michael W. McConnell, The Origins and Historical Understanding of Free Exercise of Religion 103 HARV. L. REV. (1990).

222. Id. 
value the ability to freely exercise our faith because it is a quintessential human activity that provides personal meaning to our lives. ${ }^{223}$ Religious ideas have a significant utilitarian aspect to them, and the dissemination of such ideas is protected as speech and not as free exercise. Moreover, as discussed subsequently, I do not concede that the law in question in this case, or laws of similar import, will diminish the utility of religion to society. ${ }^{224}$ Religious adherents are free to put their beliefs in action to an undiminished extent. Undoubtedly, there is a utilitarian effect of having a clear conscience. However, the protection that the First Amendment grants even the most repulsive speech - including speech offensive to religious sensibilities - is evidence that a serene mindset is not an individual entitlement. ${ }^{225}$ Finally, the utilitarian aspect of conscientious purity for one party must be weighed against the disutility of the resentment felt by those persons who believe, not unjustifiably, that the religious beliefs of others have been foisted upon them. Offensive speech merely offends. Religious exemptions to generally applicable laws can and often do have direct, actionable effects on third parties.

The Court's resort to the Dictionary Act definition of a person implies that all for-profit corporations are persons for purposes of RFRA. ${ }^{226}$ However, the Court later took great pains to emphasize that its decision was limited to the three closely-held corporations that were before it. ${ }^{227}$ If religious freedom had a utilitarian underpinning, then the nature of the corporation should be irrelevant to the issue of whether it enjoyed protection to exercise its beliefs. In contrast, Citizens United contained no such caveats. ${ }^{228}$ All corporations, from Microsoft to the sole-shareholder corporation, enjoy the rights upheld in that case. ${ }^{229}$ Moreover, the Court's holding in Smith belies any utilitarian concern for free exercise. ${ }^{230}$ Constitutionally, no accommodation for religion is required by any law of general applicability. ${ }^{231}$ This standard provides religion with less protection than commercial speech and hardly supports the notion that individual religious freedom serves a societal function similar to speech. ${ }^{232}$

A consequential analysis of speech has led to restrictions imposed on corporations that go beyond the traditional justifications for commercial speech

223. Id.

224. See infra notes 274-80, 285-88 and accompanying text.

225. See McConnell, supra note 221.

226. See supra notes 80-84 and accompanying text; see also infra notes 240-44 and accompanying text for a discussion of this issue in the context of associational rights.

227. Burwell v. Hobby Lobby Stores, Inc., 134 S. Ct. 2751, 2774-75 (2014).

228. See Citizens United v. FEC, 558 U.S. 310 (2010).

229. Id.

230. See Emp’t Div. v. Smith, 494 U.S. 872, 879 (1990).

231. See supra notes 52-53 and accompanying text.

232. At least two scholars would disagree with my opinion about the consequential importance of religion in society. See Alan J. Meese \& Nathan B. Oman, Hobby Lobby, Corporation Law, and the Theory of the Firm: Why For-Profit Corporations are RFRA Persons, 127 HARV. L. REV. F. 273, 288 (2014). 
restrictions and would not be tolerated if imposed upon an individual. For example, the federal securities laws mandate quiet periods for issuers of new securities, thereby prohibiting truthful speech and regulations, compelling corporations to provide certain information and dictate to whom such information is to be directed. ${ }^{233}$ This author knows of no instance in which the government can compel someone to exercise religious beliefs in order to serve some societal goal. Despite whatever protestations may arise from government-compelled speech, it would likely pale in comparison to the outcry that would ensue against compelled religious acts.

2. Corporate Rights Derived from the Freedom of Association.--Religious rights for corporations may be supported by a rationale that shifts such rights toward the fundamental rights end of the spectrum - individual rights of freedom of association. The opinion of the Court in Citizens United did not resort to this rationale. ${ }^{234}$ Although Justice Scalia's spirited concurrence in that case supported corporate speech rights on textual grounds, it also resorted for support to the shareholders' freedom of association. ${ }^{235}$ Justice Scalia stated that institutional speech is the speech "of many individual Americans, who have associated in a common cause. . .."236 He also stated, in true Scalia fashion, that:

[t]he dissent says that when the Framers "constitutionalized the right to free speech in the First Amendment, it was free speech of individual Americans that they had in mind." . . . That is no doubt true. All the provisions of the Bill of Rights set forth the rights of individual men and women - not, for example, of trees or polar bears. But the individual person's right to speak includes the right to speak in association with other individual persons. ${ }^{237}$

Leaving aside the Court's employment of the Dictionary Act, its rationale for supporting corporate free exercise rights was attached firmly to individual rights to freely associate. ${ }^{238}$

As we will show, Congress provided protection for people like the Hahns and Greens by employing a familiar legal fiction: It included corporations within RFRA's definition of "persons." But it is important to keep in mind that the purpose of this fiction is to provide protection for human beings. A corporation is simply a form of organization used by human beings to achieve desired ends. An established body of law specifies the rights and obligations of the people (including shareholders, officers, and employees) who are associated with a corporation in one way or another. When rights, whether constitutional or

233. See Adam Winkler, Corporate Personhood and the Rights of Corporate Speech, 30 Seattle U. L. ReV. 863, 871 (2007) (citing to 15 U.S.C. § 77e (2006); 17 C.F.R. § 240.14a-8 (2006)).

234. See Citizens United v. FEC, 558 U.S. 310 (2010).

235. See id. at 392 (Scalia, J., concurring).

236. Id.

237. Id. at 391-92 (emphasis in original) (internal citation omitted).

238. Burwell v. Hobby Lobby Stores, Inc., 134 S. Ct. 2751, 2767 (2014). 
statutory, are extended to corporations, the purpose is to protect the rights of these people. For example, extending Fourth Amendment protection to corporations protects the privacy interests of employees and others associated with the company. Protecting corporations from government seizure of their property without just compensation protects all those who have a stake in the corporations' financial well-being. And protecting the free-exercise rights of corporations like Hobby Lobby, Conestoga, and Mardel protects the religious liberty of the humans who own and control those companies. ${ }^{239}$

The Court's resort to the associational rights of individuals to support recognition of a corporate right appears inconsistent with its concomitant reliance on the Dictionary Act to justify its recognition of corporate personhood for RFRA purposes. The Court made clear that personhood status for some, but not all, corporations could not be squared with the Dictionary Act's language. ${ }^{240}$ But surely associational rights are not implicated in all corporate structures. The Court's decision, in theory, would support an RFRA claim by any corporation, including publicly traded corporations. Although the majority limited its holding to the three particular closely-held corporations it had before it, whether other corporations are successful in their RFRA claims would be predicated on whether their ownership structure cast doubt on the sincerity of their beliefs. ${ }^{241}$ By the Court's reasoning, ownership structure is not a per se bar to bringing an RFRA claim. ${ }^{242}$ For example, publicly traded corporations may have classes of stock with voting stock concentrated in the hands of the founder. ${ }^{243}$ Google, Facebook, and Viacom are three of the more prominent examples of such equity structures. $^{244}$ It is not inconceivable that a public corporation, whose vote is controlled by a founding family, can make a legitimate RFRA claim based on the founding family's religious beliefs. For that matter, Hobby Lobby Stores could offer shares to the public - it is quite a substantial company-and the Green family could retain the voting shares.

In Citizens United, Justice Scalia did not clarify which individuals' associational rights are to be given succor. ${ }^{245}$ In Hobby Lobby Stores, the Court made it clear that corporate personhood is designed to protect "the humans who own and control those companies." ${ }^{246}$ In other words, only shareholders have the

239. Id. at 2768 (emphasis in original).

240. See supra note 84 and accompanying text.

241. See supra notes 107-09 and accompanying text.

242. Burwell, $134 \mathrm{~S}$. Ct. at 2774-75.

243. See Miriam Gottfried, Investors Beware Powers of Supervoting Shares, WALL ST. J., Dec. 17, 2012, at C8.

244. See id. The ability to retain control had a significant effect on the decision by Alibaba Group Holdings, Ltd.'s management to list its shares in the United States after the conclusion of its initial public offering. Hong Kong stock exchange rules would not permit the share structure desired by the company. See Matt Jarzemsky \& Juro Osawa, Alibaba Jabs at Hong Kong Bourse, Wall St. J., Sept. 27, 2013, at C3.

245. Citizens United v. FEC, 558 U.S. 310, 385-394 (2010).

246. Burwell, 134 S. Ct. at 2756. 
associational rights that protect religious liberty derivatively. ${ }^{247}$ This ignores, however, the fact that the individuals who choose to associate in corporate form include employees, customers, suppliers, debt holders, and other constituencies. Just what is their common cause?

Unlike members of religious organizations, the common cause of shareholders and other constituencies is commercial in nature. Although the Court rightly noted that the profit motive in and of itself does not preclude a purpose to advance other values, it is highly unlikely that such other values are shared by all constituents who choose to associate under a corporate umbrella. In NAACP v. Alabama, the Court held that the right of association, regardless of whether the beliefs sought to be advanced pertain to political, economic, religious, or cultural matters, is protected against state actions that go beyond the establishment of direct impediments to the ability of individuals to associate. ${ }^{248}$ However, indirect restraints are examined to determine their likelihood of imposing a substantial restraint upon the exercise of members' rights to freely associate. ${ }^{249}$ Consequently, the nexus between the group's common cause and the derivative right in question - in this case free exercise - is relevant to whether the state's impediment significantly and meaningfully stifles members' ability to associate. ${ }^{250}$ Members do not associate in a for-profit corporate form to advance religious beliefs. The advancement of such beliefs speaks to the method in which the common cause of the for-profit corporation is attained but it is not the raison d'etre of the entity. If it were, then the corporation should have been organized as a religious non-profit entity. The fact that non-profit status may come at the price of foregoing lobbying and political activity should not be license to mask the true nature of an organization to avoid legal restrictions that the organization's promoters find distasteful. ${ }^{251}$

The nature of the modern corporation casts doubt on the legitimacy of corporate personhood as a tool to vindicate individual associational rights. Restrictions imposed on a single shareholder corporation do not implicate any associational rights. ${ }^{252}$ Opposition to such restrictions is based on the notion that it is unfair to make a person choose between religious liberty and the legal benefits of incorporation. ${ }^{253}$ However, if a corporation is a person then the focus should be solely on the corporation in this respect. ${ }^{254}$ The corporation did not sacrifice any religious liberty because it never had any such liberty to sacrifice. ${ }^{255}$ At the other end of the spectrum, associational rights weaken considerably in a

247. See id.

248. NAACP v. Alabama, 357 U.S. 449, 460-61(1958).

249. See id. at 462.

250. See id. at 460-63.

251. See supra note 90 and accompanying text.

252. Meese \& Oman, supra note 232, at 287.

253. Id. at 292-93.

254. Id. at 288 .

255. Id. at 291. 
large publicly traded corporation. ${ }^{256}$ The notion that associational rights are implicated in a corporation with several hundred thousand or millions of shareholders, the identity of whom changes by the minute, is nonsense. Moreover, the prevalence of institutional shareholders begs the question of just how far removed may individuals be from the corporate entity in question before the right to association with other individuals becomes too attenuated to be taken seriously. ${ }^{257}$ The law has recognized that rights to freely associate are more likely to give way to other competing goals as the number of members in the association grows larger. ${ }^{258}$ Title VII of the Civil Rights Act of 1964 is a case in point. ${ }^{259}$

Associational rights in the context of closely held corporations that are owned by a limited number of like-minded shareholders are also problematic. For example, should a corporation whose ownership is diffused among family members, like the three corporations in this case, be considered a single shareholder corporation? If ownership was allocated among family members for wealth transfer tax purposes, then perhaps associational interests weaken considerably. In such cases, the dilemma for the founding member is not her inability to associate with others but her inability to attain the legal benefits of incorporation without any effect on religious exercise. Other related questions arise. For instance, what effect does trust ownership of stock have on associational rights if not all of the trust beneficiaries share the same religious fervor or if the trust beneficiaries are yet unborn?

Finally, a single minded focus on the associational rights of the owners of a corporation would appear to preclude any RFRA claim by other corporate constituents. For example, it is quite possible that the religious sensibilities of an employee benefits manager of a closely held corporation, whose responsibilities include the communication of contraception benefits to participants, are offended to a greater degree than the owners of the corporation. At best, such an employee could take refuge in Title VII's reasonable accommodation provisions. ${ }^{260}$ It is difficult to find a principled distinction between the heightened religious protections for the owners of the corporation and the modest religious protections afforded to employees under Title VII. ${ }^{261}$ The fact that an employee voluntarily chose such employment is not satisfactory; the owners voluntarily chose their form of business.

256. Id. at 289.

257. Individuals are at least two levels removed from the corporation in question to the extent that corporate shares are held by mutual funds, pension plans, hedge funds, and other institutional investors. To the extent that such funds are aggregates of other funds - a fund of funds, for example-individuals are even more remote from the corporation in question.

258. Meese \& Oman, supra note 232, at 285.

259. The freedom to associate with persons of one's choosing is overcome by the state's interest in a workplace free from discrimination on the basis of race, color, gender, religion, and national origin if fifteen or more persons are employed by the employer for a statutorily determined period. See 42 U.S.C. $\S \S 2000$ e(b), 2000e-2(a) (2010).

260. See infra notes 303-04 and accompanying text.

261. 42 U.S.C. $\S 2000$ e (2014). 
The Court's rationale for not extending to corporations the Fifth Amendment right against self-incrimination is instructive:

The right of a person under the Fifth Amendment to refuse to incriminate himself is purely a personal privilege of the witness. It was never intended to permit him to plead the fact that some third person might be incriminated by his testimony, even though he were the agent of such person. A privilege so extensive might be used to put a stop to the examination of every witness who was called upon to testify before the grand jury with regard to the doings or business of his principal, whether such principal were an individual or a corporation. The question whether a corporation is a "person" within the meaning of this Amendment really does not arise, except perhaps where a corporation is called upon to answer a bill of discovery, since it can only be heard by oral evidence in the person of some one of its agents or employes [sic]. The Amendment is limited to a person who shall be compelled in any criminal case to be a witness against himself, and if he cannot set up the privilege of a third person, he certainly cannot set up the privilege of a corporation. ${ }^{262}$

Leaving aside the differences between the right against self-incrimination and the right of free exercise, the Court's Fifth Amendment jurisprudence makes clear that certain legal protections make no sense in a corporate context.

3. Individual Shareholder Standing.-Denial of corporate personhood should not preclude an RFRA claim by the individual shareholders of a corporation. Standing for such a claim should be granted to individuals directly or to the corporation in an associational capacity. Article III standing "enforces the Constitution's case-or-controversy requirement" and "serves to prevent the judicial process from being used to usurp the powers of political branches." 263 Standing will be maintained only if the injury alleged is concrete, particularized, and actual or imminent; is fairly traceable to the challenged action; and is redressable by a favorable ruling. ${ }^{264}$ Moreover, the fact that denial of standing to a particular party or parties would result in no one with standing to challenge a particular law "is not a reason to find standing." ${ }^{265}$ It is not clear whether a shareholder can assert a harm that derives from a government requirement

262. Hale v. Henkel, 201 U.S. 43, 69-70 (1906).

263. Clapper v. Amnesty Int'l USA, 133 S. Ct. 1138, 1146 (2013) (citations omitted); Lujan v. Defenders of Wildlife, 504 U.S. 555, 559-62 (1992).

264. Clapper, 133 S. Ct. at 1148 (citing to Monsanto Co. v. Geertson Seed Farms, 130 S. Ct. 2743, 2752 (2010)); Lujan, 504 U.S. at 560-61.

265. Clapper, $133 \mathrm{~S}$. Ct. at 1154 (citing to various cases). Despite this statement, the Court disagreed that the warrantless acquisition of intelligence authorized by the Foreign Intelligence Surveillance Act could not be challenged by anyone. See id. at 1154-55. The Court may have been too optimistic in this regard. See Adam Liptak, A Secret Surveillance Program Proves Challengeable in Theory Only, N.Y. TIMES, July 16, 2013, at A11 (reporting that federal prosecutors have refused to make required disclosures to defendants of information derived from surveillance). 
imposed on the corporation that she owns. The court did not reach this issue in this case but several judges in the Tenth Circuit reached opposite conclusions in this respect. ${ }^{266}$ The court has set forth a three-prong test for associational standing, the ability of an institution to represent its members, and the factors to be considered are: whether its members would otherwise have standing to sue in their own right; the interests the organization seeks to protect are germane to the organization's purpose; and whether neither the claim asserted nor the relief requested requires the participation of individual members in the lawsuit. ${ }^{267}$ Consequently, whether associational standing would maintain depends on the answer to the question that divided the Tenth Circuit judges. ${ }^{268}$ It seems anomalous that shareholder standing is not maintained since the cognizable harm visited upon the corporation is premised on the harm inflicted upon the shareholders. In any event, one thing this author has learned about standing is that it is what the Court says it is. ${ }^{269}$ Shareholders should be able to assert their claims.

An individual RFRA claim brings into stark relief the issues of free exercise and the substantiality of any burden imposed on such exercise at the individual level where it belongs. The Court in Hobby Lobby Stores had the opportunity to place some principled boundary on just what is encompassed by the term "exercise of religion." 270 Unfortunately, it failed to do so.

\section{B. Free Exercise or Clear Conscience}

RFRA protects the exercise of religion. ${ }^{271}$ The statute, to the extent it attempts to define exercise, defines the term circularly. The exercise of religion is defined as any exercise of religion, whether or not compelled by, or central to, a system of religious belief. ${ }^{272}$ Justice Scalia, in the majority opinion in Smith,

266. See Hobby Lobby Stores v. Sebelius, 723 F.3d 1114, 1152-56 (10th Cir. 2013) (Gorsuch, Kelly, Tymovich, J.J., concurring) (opining that shareholders have standing); Sebelius, 723 F.3d at 1161 (Bacharach, J. concurring) (opining that the shareholders do not have standing); Sebelius, 723 F.3d at 1177 (Briscoe, Lucero, J.J.) (concurring in part, dissenting in part) (opining that the shareholders do not have standing ); Sebelius, 723 F.3d at 1185-90 (Matheson, J.) (concurring in part, dissenting in part ) (opining that shareholders have standing). The majority opinion did not reach this issue. Sebelius, 723 F.3d at 1126 (majority opinion).

267. Hunt v. Wash. State Apple Adver. Comm'n, 432 U.S. 333, 343 (1977).

268. Sebelius, 723 F.3d 1114.

269. See Matthew A. Melone, A Leg to Stand on: Is There a Legal and Prudential Solution to the Problem of Taxpayer Standing in the Federal Tax Context, 9 PITT. TAX REV. 97, 115-45 (2012).

270. Burwell v. Hobby Lobby Stores, Inc., 134 S. Ct. 2751 (2014).

271. Religious Freedom Restoration Act of 1993, Pub. L. 103-141, § 5(4), 107 Stat. at 1489.

272. 42 U.S.C. $\S \S 2000 \mathrm{bb}-2(4), 2000 \mathrm{cc}-5$ (7)(2010). As originally enacted, RFRA defined the exercise of religion as the exercise of religion under the First Amendment. See Religious Freedom Restoration Act of 1993, Pub. L. 103-141, § 5(4), 107 Stat. at 1489. The statute was amended to read in its current form by RLUIPA, Pub. L. 106-274, § 7(a)(3), 114 Stat. 803, 806 (2000) —a fact 
stated that

[t]he free exercise of religion means, first and foremost, the right to believe and profess whatever religious doctrine one desires. . . But the "exercise of religion" often involves not only belief and profession but the performance of (or abstention from) physical acts: assembling with others for a worship service, participating in sacramental use of bread and wine, proselytizing, abstaining from certain foods or certain modes of transportation. It would be true, we think (though no case of ours has involved the point), that a state would be "prohibiting the free exercise [of religion]" if it sought to ban such acts or abstentions only when they are engaged in for religious reasons, or only because of the religious belief that they display. It would doubtless be unconstitutional, for example, to ban the casting of "statues that are to be used for worship purposes," or to prohibit bowing down before a golden calf.

Respondents in the present case, however, seek to carry the meaning of "prohibiting the free exercise [of religion]" one large step further. They contend that their religious motivation for using peyote places them beyond the reach of a criminal law that is not specifically directed at their religious practice, and that is concededly constitutional as applied to those who use the drug for other reasons. They assert, in other words, that "prohibiting the free exercise [of religion]" includes requiring any individual to observe a generally applicable law that requires (or forbids) the performance of an act that his religious belief forbids (or requires). As a textual matter, we do not think the words must be given that meaning. ${ }^{273}$

As Justice Scalia noted, the exercise of religion means the belief in the tenets of one's faith, the ability to profess such faith, the performance of physical acts that advance one's faith, and the abstention from physical acts that contradict one's faith. ${ }^{274}$ The objection to the Smith decision was based on the fact that government burdens placed on free exercise were not subjected to searching scrutiny and Congress capitulated to this objection by enacting RFRA. ${ }^{275}$ The free exercise rights of the respondent in Smith - his ability to fully participate in a religious ceremony - clearly were burdened. Smith does not stand for the proposition that burdens placed on conscience by generally applicable laws, without more, is a burden on free exercise. ${ }^{276}$ Quite the contrary, it is the requirement (or prohibition) "of an act that . . religious belief forbids (or requires)" that triggers whatever scrutiny of that requirement or prohibition is

that the majority considered to be significant. See supra notes 100-01 and accompanying text.

273. Emp't Div. v. Smith, 494 U.S. 872, 877-78 (1990) (emphasis added).

274. Id.

275. Burwell, 134 S. Ct. at 2756.

276. Emp't Div., 494 U.S. at 878. 
appropriate. $^{277}$

To be sure, the intent of Congress in enacting RFRA was to provide statutory protection for religious exercise for which the Court denied constitutional protection. ${ }^{278}$ Smith, however, involved a physical act directly connected to the practice of faith. The payment of health insurance premiums by a corporate enterprise is not an action that has inherent religious connotations. The record in Hobby Lobby Stores leaves no doubt that the shareholders believed that the provision of insurance coverage for certain products or services assisted in the commission of an act to which they conscientiously objected. ${ }^{279}$ However, RFRA guarantees the right to free exercise, not the right to a clear conscience. ${ }^{280}$ The provision of insurance does not inhibit the shareholders to believe that abortion is morally wrong, to profess that belief, or to pray, take sacraments, and engage in other religious actions that buttress that belief.

RFRA should be inapplicable to government actions that are not targeted at religion and whose only connection to religion is the disturbance of conscience. For example, RFRA protections should extend to environmental laws that prevent the construction or use of a religious facility, trade laws that prevent the purchase of religious objects, narcotics laws that prohibit the use of a product in a religious service, health laws that mandate vaccinations, or animal protection statutes that prohibit ritual sacrifice. ${ }^{281}$ These types of laws do not merely burden the conscience but also burden the exercise of religion because they prohibit or require actions that, in and of themselves, have religious meaning. If, for sake of argument, the religious beliefs of the shareholders of Hobby Lobby Stores, Conestoga Wood Specialties, or Mardel caused them to believe that the provision of health insurance, per se, was morally wrong, then the mandate would place a burden on their free exercise rights. The objections to participation in the Social Security system by the Amish in Lee were not to the consequences of such participation but to the participation itself. ${ }^{282}$ At that point it becomes appropriate to employ the substantial burden and least restrictive means tests.

The invocation of RFRA to alleviate the burden of conscience leaves RFRA without a limiting principle, thus exposing the government to the vagaries of the courts in determining whether the burden is substantial and whether there is, or is not, a least restrictive means in achieving an objective. It should not go that

277. Id.

278. Burwell,134 S. Ct. at 2768-69.

279. Id. at 2757.

280. Religious Freedom Restoration Act of 1993, Pub. L. 103-141, § 5(4), 107 Stat. 1489.

281. In a case decided not long after Smith, the Court held that local ordinances prohibiting animal sacrifice in religious ceremonies were unconstitutional. See supra note 53. In that case, the Court found that the ordinances targeted a particular religious faith. Id. This author does not mean to imply that laws set forth by way of example would fail to pass muster under RFRA. Such laws, so long as they did not target religious practices, very well may meet RFRA's compelling interest and least restrictive means tests. However, such laws unquestionably would burden the exercise of religion.

282. See United States v. Lee, 455 U.S. 252, 256-57 (1982). 
far. Smith itself was an attempt by the Court to prevent the constitution from permitting "every citizen to become a law unto himself." 283 Congress made a political choice to subordinate secular policy objectives to religious freedom to an extent. However, if RFRA is employed to protect conscience and nothing more, then RFRA will have achieved what the Court feared in Smith. ${ }^{284}$

Ironically, the disturbance of conscience is often the catalyst for greater, not less, religious exercise. Particularly controversial actions by the government, be they the use of torture at Guantanamo, ${ }^{285}$ drone strikes on civilians, ${ }^{286}$ legislation sanctioning gay marriage, ${ }^{287}$ or a judicial decision that is solicitous of abortion rights, ${ }^{288}$ often have a propensity to agitate religious objectors into action. Arguably, such actions encourage, not burden, free exercise. Despite its failure to limit RFRA's application in this context, the Court had the opportunity to limit the statute's application by subjecting asserted claims of substantial burdens to some meaningful scrutiny. Again, it declined to do so.

\section{Substantial Burden}

Because the RFRA requires that any substantial burden placed on religious exercise run the gauntlet of the least restrictive means test, a symbiotic relationship should exist between the interpretation of the terms "exercise" and

283. Emp't Div. v. Smith, 494 U.S. 872, 879 (199) (quoting Minersville Sch. Dist. Bd. of Ed. v. Gobitis, 310 U.S. 586, 594-595 (1940)); Reynolds v. United States, 98 U.S. 145, 166-67 (1879)).

284. One prominent scholar posits that historical support exists for a broader concept of free exercise in the context of state, as opposed to federal, action. He asserts that the First Amendment right of free exercise, as incorporated into the Fourteenth Amendment, may have taken on a more capacious meaning in the aftermath of the Civil War than the meaning intended almost a century before by the Framers. See AKHIL ReEd Amar, THE BiLl of Rights 254-57 (1998). I know of no case in which the Free Exercise Clause has been applied more vigorously against the states than it has been applied against the federal government. In any event, RFRA applies only to the federal government. See supra note 56 and accompanying text.

285. See generally Ctr. FOR CONSTitutional Rights, Report on TORTURE AND CRUEL, Inhuman, AND Degrading TREATMEnt of Prisoners at GuAntanamo BAy, CubA (2006), available at http://ccrjustice.org/files/Report_ReportOnTorture.pdf, archived at http://perma.cc/NW9T-DADD (describing the some of the conditions present at Guantanamo Bay).

286. See generally Matt Sledge, The Toll of 5 Years of Drone Strikes: 2,400 Dead, THE HUFFINGTON POST (Jan. 23, 2014, 7:32 PM) http://www.huffingtonpost.com/2014/01/23/obamadrone-program-anniversary_n_4654825.html, archived at $\mathrm{http}: / /$ perma.cc/HW76-43VZ (about the civilian impact of drone strikes).

287. See generally 31 States with Legal Gay Marriage and 19 States with Same-Sex Marriage Bans, ProCON.ORG (last updated Oct. 20, 2014), http://gaymarriage.procon.org/view.resource. php?resourceID $=004857$, archived at http://perma.cc/UH2L-YWKL (a list of which states allow same-sex marriage).

288. See generally Important Supreme Court Cases, The Pro-Cholce Public Educ. Project, http://www.protectchoice.org/section.php?id=16 (last visited Oct. 14, 2014), archived at http://perma.cc/U8V8-DKDW (a list of important cases regarding abortion). 
"substantial burden." 289 A less capacious construction of what constitutes the exercise of religion very well may justify the Court's insistence that any judicial inquiry into the substantiality of a burden on such exercise is untoward. ${ }^{290}$ However, the lack of any principled limitation on the meaning of religious exercise should prompt the courts to examine whether any burden on such exercise is substantial. Otherwise, RFRA becomes anarchical. It is true that under Title VII, sincerely held religious beliefs are not subjected to any objective standard and that beliefs themselves are subject to the statutory protections. ${ }^{291}$ However, Title VII requires only that employers make reasonable accommodations for religion and do require that workplace practices employ the least restrictive means to achieve the employer's objectives. ${ }^{292}$ Far reaching religious protection may be appropriate when such protection does not require the offending party to justify her actions under a draconian standard such as the least restrictive means test.

The notion that the judiciary has no business questioning the substantiality of a burden in this context is illogical. The law imposes objective standards on beliefs in other contexts and appears to do so without inordinate difficulty. Many crimes are based on actions that are inherently benign but become criminal when accompanied by criminally negligent beliefs. Justifiable self-defense requires a reasonable belief in the threat of imminent death or serious bodily harm. ${ }^{293}$ Why is it appropriate to subject a person's sincere belief that she faced such a threat to some workable standard but inappropriate to subject a claim that a particular burden on free exercise is substantial?

Such an inquiry would be no more, and would perhaps be even less, intrusive than an inquiry into the sincerity of the religious beliefs in question - an inquiry that the judiciary can and does undertake. ${ }^{294}$ Moreover, the application of an objective standard does not call into question whether or not the person genuinely believes the burden at issue is substantial. It merely requires a court to distinguish between sensitivities that likely exist generally from those that exist idiosyncratically. Every person has the right to attach whatever religious meaning to an act their conscience demands. ${ }^{295}$ The law, however, should not be

289. Religious Freedom Restoration Act of 1993, Pub. L. 103-141, § 2000bb, 107 Stat. 1489.

290. See supra notes 133-35 and accompanying text.

291. See, e.g., Redmond v. GAF Corp., 574 F.2d 897 (7th Cir. 1978); see also 29 C.F.R. § 1605.1 (2009); Welsh v. United States, 398 U.S. 333 (1970).

292. See 42 U.S.C. $\$ \S 2000 \mathrm{e}(\mathrm{j}), 2000 \mathrm{e}-2$ (a)(2010). An accommodation is not reasonable if it requires more than a de minimis cost to implement. See 29 C.F.R. $§ 1605.2(e)(1)$ (2009).

293. "The defender must have believed that he was in imminent peril of death or serious bodily harm, and that his response was necessary to save himself therefrom. These beliefs must not only have been honestly entertained, but also objectively reasonable in light of the surrounding circumstances." United States v. Peterson, 483 F.2d. 1222, 1230 (D.C. Cir. 1973) (emphasis added); see generally Re'em Segev, Fairness, Responsibility and Self-Defense, 45 SANTA CLARA L. REV. 383 (2005).

294. See supra notes 107-09 and accompanying text.

295. Burwell v. Hobby Lobby Stores, Inc., 134 S. Ct. 2751, 2804 (2014) 
hostage to the vagaries of the hypersensitive.

On the one hand, the Court stated that wherever the line is drawn to demarcate a person's proverbial Rubicon " "it is not for us to say that the line he drew was an unreasonable one." ${ }^{296}$ On the other hand, the Court proceeded to tally up the penalties imposed under the tax code for the failure to provide either health insurance in general or contraception coverage in particular. ${ }^{297}$ If it is not for the Court to say whether or not the limits of personal tolerance have been reached, then the relevance of the magnitude of financial penalties for noncompliance escapes this author. If, in fact, the Court was testing the substantiality of the burden by some reasonableness or other such standard, then it misunderstood the burden that it was testing.

The contraception mandate is, at its essence, a requirement that a private person indirectly fund an action that she finds religiously objectionable. The burden that should be examined is not the financial penalty for non-compliance but the burden imposed on religious exercise by compliance with the mandate. The burden must arise from compliance with the challenged law. For example, the religious burden imposed by the use of tax dollars for objectionable ends does not arise from the fact that the failure to pay taxes subjects a tax evader to fines and possible imprisonment. ${ }^{298}$ Rather, the burden in such cases is the harm to the conscience that arises from the payment of the taxes. ${ }^{299}$ This is the burden that RFRA subjects to scrutiny. As previously noted, this author argues that an imposition on conscience, without more, is not a burden on exercise at all. ${ }^{300}$ Assuming arguendo that such a burden is, in fact, a burden on free exercise, it is not substantial by any reasonable standard.

296. Id. at 2757 (quoting Thomas v. Review Bd. of Ind. Emp't Sec. Div., 450 U.S. 707, 715 (1981)). The Court distinguished the facts in this case from the facts in Tilton v. Richardson, 403 U.S. 672 (1971) and Board of Education of Central School District No. 1 v. Allen, 392 U.S. 236 (1968). In those cases the Court rejected the assertion that the use of general tax revenues to subsidize the secular activities of religious institutions violated the Free Exercise Clause. However, the challenges in those cases were not based on the religious beliefs of the challengers but instead on their views of proper church-state relations. Burwell, 134 S. Ct. at 2779.

297. Burwell, $134 \mathrm{~S}$. Ct. at 2776.

298. Various criminal sanctions are set forth in the Internal Revenue Code. Willful attempts to evade or defeat the imposition or payment of any tax is a felony punishable by a fine of not more than $\$ 100,000$, not more than imprisonment for five years, or both. I.R.C. $\$ 7201$ (CCH 2014). The willful failure to adhere to any requirement to keep records or supply information is a misdemeanor punishable by a fine of not more than $\$ 25,000$, not more than imprisonment for one year, or both. Id. $\S 7203$. The making of fraudulent statements, concealment of property, or the withholding, falsification, or destruction of records is a felony that is subject to a fine of not more than $\$ 100,000$, up to three years imprisonment, or both. Id. $\S 7206$. Finally, the willful filing of a fraudulent or false return is subject to a fine of not more than $\$ 10,000$, not more than imprisonment for one year, or both. Id. $\S 7207$. In addition a variety of civil penalties may be imposed. See, e.g., id. $\S \S 6662,6663$.

299. Emp't Div. v. Smith, 494 U.S. 872, 880 (1990).

300. See supra notes 271-84 and accompanying text. 
Justice Ginsburg argued that the intervening acts of the insured and medical providers make any such burden too attenuated to be considered substantial. ${ }^{301}$ The independent intervening acts of third parties, by themselves, should not be sufficient to defeat a substantiality claim. For example, a government mandate that an employer must pay for an abortion once the patient has submitted it a bill may go too far despite the intervening acts of the patient and her medical provider. The substantiality of the alleged burden should be tested by reference to unchallenged impositions on free exercise to determine whether the burden at issue differs in kind from such other impositions. If similar burdens have been managed without unduly burdening free exercise rights, then the challenged burden is not substantial. The contraception mandate is similar in kind to a host of other government impositions.

Virtually all government edicts impose a burden on something. Many longstanding legal requirements impose indirect burdens on the exercise of religion. The obligation to pay income taxes reduces the amount of funds that an individual could otherwise use to support institutions that advance her faith. This type of burden is visited not only upon conscience but also upon the ability to act. Title VII of the Civil Rights Act of 1964 not only prohibits religious based discrimination in hiring but also requires that reasonable accommodations be made for employees whose faith may be anathema to the faith of their employers. ${ }^{302}$ The courts, in recent years, have become more liberal in protecting religious liberty under the reasonable accommodation provisions of Title VII. ${ }^{303}$ The expansive religious protections afforded employees can be used analogously to provide support for expansive RFRA protections. That may be so, but the more protective Title VII is of employee religious freedom, the more burdens it places on employers, and these burdens are not necessarily financial in nature. ${ }^{304}$ It is quite possible that certain religious beliefs or practices that must be accommodated are deeply offensive to the employer's religious beliefs.

The Court addressed the possibility that its decision would lead the country down the slippery slope of multitudinous claims of exemption from a variety of generally applicable laws. ${ }^{305}$ However, the Court discounted that possibility because many, if not most, of the challenged laws may very well employ the least restrictive means to achieve a compelling government objection. ${ }^{306}$ However, existing legal requirements of this sort are not substantial burdens to free exercise regardless of whether they achieve their objectives by the least restrictive means.

Rather than categorizing the requirement to comply with legal duties imposed on society at large as a burden, it is just as reasonable to classify an exemption from such duties as a matter of legislative grace and not as an entitlement. The

301. Burwell, 134 S. Ct. at 2787 (Ginsburg, J., dissenting).

302. See supra notes 291-92 and accompanying text.

303. See generally Katz, supra note 173, at 110.

304. Id.

305. Adeyeye v. Heartland Sweeteners, LLC, 721 F.3d 444, 452 (7th Cir. 2013).

306. Burwell, 134 S. Ct. at 2779. 
Roman Catholic Church is not entitled to tax exempt status. ${ }^{307}$ Instead, it and other religious institutions are exempted for policy reasons as a matter of legislative grace. ${ }^{308}$ Similarly, reasonable individuals consider the tax deduction permitted for donations to religious institutions as a benefit that subsidizes religion rather than partial relief from the burden imposed on their free exercise rights by the tax code. ${ }^{309}$ Reasonable people understand that it is impossible to live in an ordered society without some form of government imposition on their freedom to act - whether religiously or otherwise.

The contraception mandate is similar in kind to a host of other burdens to which persons engaged in for-profit activities have become accustomed. The essence of the shareholders' objections in this case is the fact that they are compelled to part with their funds and that such funds indirectly may be used to facilitate activities to which they object. This type of compelled activity is commonplace in the for-profit world. The income taxes imposed on corporations' profits fund government activities, such as grants for organizations such as Planned Parenthood, that may be morally repugnant to the shareholders. ${ }^{310}$ Perhaps the connection between the payment of income taxes and the government expenditures made possible by taxes is too attenuated to form an apt comparison to the contraception mandate. Other indirect burdens are not so attenuated.

Hobby Lobby Stores employs approximately 13,000 individuals. ${ }^{311}$ It is a safe assumption, given Title VII and state anti-discrimination statutes, that many of its employees do not share the same faith as the shareholders or, if they do, do not possess the same fervor as the shareholders. Consequently, unless the shareholders are willfully blind, surely they must be aware that the paycheck that they provide to certain employees will be used to engage in activities that are deeply disturbing to their faith. Do the shareholders genuinely believe that contract law should not enforce their obligation to pay an employee if they can show that the money will be used to pay for an abortion or a damnable lifestyle? If not, then this author fails to see any principled difference between this example and the contraception mandate with respect to the extent of the burdens that each imposes. Wheaton College believes that the accommodations offered by the administration to religiously-affiliated employers do not relieve the substantial burden on its free exercise imposed by the contraception mandate. ${ }^{312}$ The accommodation severs the connection between the employer funds and the objectionable actions. ${ }^{313}$ In effect, Wheaton's only complicity in the use of the

307. See generally Austin Cline, Why Taxation of Religion Matters, ABOUT.COM, http://atheism.about.com/od/churchestaxexemptions/a/whyitmatters.htm(last visited Oct. 14, 2014), archived at http://perma.cc/HS6N-KHHX (for a general overview of the issue of taxing churches).

308. See I.R.C. $\S \S 501(a), 501(c)(3)(2014)$.

309. See id. $\S \S 170(\mathrm{a}), 170(\mathrm{c})(2)(\mathrm{B})$.

310. Burwell, $134 \mathrm{~S}$. Ct. at 2784.

311. See supra note 66 and accompanying text.

312. See supra note 160 and accompanying text.

313. See supra note 40 , infra note 160 and accompanying text for a discussion of these 
objectionable products under the accommodation procedures would be its employment of women who someday may choose to use such products. Likewise, direct government funding of contraceptive products for women whose employer does not offer such coverage would be subject to similar objection.

The payment of wages and the provision of contraception coverage are activities that do not prevent the shareholders from actively exercising their faith, result in objectionable activities only through the intervening acts of others, and are disturbing to conscience and nothing more. The shareholders of all three corporations willingly accepted a host of financial obligations that may result in activities that offend their religious sensibilities when they decided to enter into the stream of commerce. The contraception mandate is one of these financial obligations, no different in kind than many other such obligations. The Court's willingness to extend the definition of religious exercise to the entitlement of a clear conscience requires some objective limitation on claims of substantiality. The fact that the shareholders have managed to prosper under similar burdens is objective evidence that the burden imposed by the mandate is not substantial in an objective sense.

\section{Least Restrictive Means}

Additional support for limitations on the scope of actions that constitute the exercise of religion, or for the employment of some standard by which to test substantiality claims, is that such limitations, or such a standard, will reduce to a significant degree the frequency in which the courts are required to test government actions against other possible alternatives. Thirty years ago the Court recognized the inherent limitations of the judicial branch in policy formulation. ${ }^{314}$

Under the Court's seminal decision in Chevron U.S.A., Inc. v. Natural Resources Defense Council, Inc., administrative agency actions that had been subject to notice and comment are subjected to a deferential standard of review. ${ }^{315}$ Under that standard, if the statute that is the subject of the agency action does not directly address the precise question at issue then the action will not be disturbed unless it is found to be arbitrary, capricious in substance, or manifestly contrary to the statute. ${ }^{316}$ Such deference is warranted because, according to the Court, " $[t]$ he power of an administrative agency to administer a congressionally created ... program necessarily requires the formulation of policy and the making of rules to fill any gap left, implicitly or explicitly, by Congress." ${ }^{317}$ Moreover, the modern administrative state often requires agencies, in formulating policy to possess specialized knowledge that goes beyond the "ordinary knowledge"

accommodations.

314. Chevron U.S.A., Inc. v. Natural Res. Def. Council, Inc. 467 U.S. 837 (1984).

315. $I d$.

316. See United States v. Mead, 533 U.S. 218, 277 (2001).

317. Chevron, 467 U.S. at 843. 
possessed by the courts. ${ }^{318}$ Justice Ginsburg more recently stated the rationale for judicial deference to agency action: "The expert agency is surely better equipped to do the job than individual judges issuing ad hoc, case by case injunctions. Federal judges lack the scientific, economic, and technological resources an agency can utilize in coping with issues of this order." ${ }^{\prime 319}$

Courts should adjudicate RFRA claims within the spirit of Chevron and not lose sight of the fact that their role is not to craft policy - a point apparently lost on the Court in Hobby Lobby Stores. The method in which the Court employed the statute's least restrictive means test appears at odds with its recognition of the inherent limitations of the judiciary in Chevron. The Court's belief that the accommodation made for certain religious non-profit organizations evidenced that the contraception mandate was not the least restrictive means of achieving the government's asserted objective. Notwithstanding Justice Ginsburg pointed dissent in this regard, the majority's use of an existing administratively created alternative certainly is understandable and defensible. ${ }^{320}$

Problematically, however, the Court also believed that direct government payment for the disputed services was a least restrictive means of achieving the objectives of the contraception mandate: "The most straightforward way of doing this would be for the government to assume the cost of providing the four contraceptives at issue who are unable to obtain them under their health insurance policies due to their employers' religious objections." 321 The Department of Health \& Human Services did not produce cost estimates or other statistics refuting the Court's assumption that the cost of such coverage to the government would be minor. ${ }^{322}$

This is dangerous ground on which the Court has ventured because the same can be said of various government burdens. For example, the government can bear the cost of insurance coverage for spouses in same-sex marriages if the employer has religious objections to such marriages. ${ }^{323}$ In effect, under the Court's reasoning, for any program not expressly exempted from RFRA's requirements, the government either must anticipate religious objections and score the cost of providing direct government funding or be prepared to do so in litigation. Moreover, the short-term costs of government funding do not take into

318. Id. at 844 .

319. Am. Elec. Power Co. v. Conn., 131 S. Ct. 2527, 2539-40 (2011).

320. Whether this alternative will function smoothly is questionable. See, e.g., Louise Radnofsky, Coverage Alternatives Face Hurdles, WALL ST. J., July 2, 2014, at A6; Lauren Weber, Hiring Process Just Got Dicier, WALl St. J., July 2, 2014, at B7.

321. Burwell v. Hobby Lobby Stores, Inc., 134 S. Ct. 2751, 2780 (2014).

322. Id. at 2781 .

323. It is inevitable perhaps that such a challenge will be made. Religious groups already have begun to pressure the Obama Administration to provide religious exceptions to his executive order that prohibits federal contractors from discriminating against gay and transgender individuals. See Exec. Order No. 13672, 79 Fed. Reg. 42971 (July 23, 2014) (amending Exec. Order Nos. 11246 and 11478); see also Laura Meckler, Contractors Face Obama Ban Against LGBT Bias, WALL ST. J., July 19, 2014, at A4; Op-ed, Taxpayer-Financed Bigotry, N.Y. TIMES, July 12, 2014, at A16. 
account dynamic factors such as the effect that modifications to existing programs will have on market prices and on the behavior of the market participants. Such factors often are beyond the predictive ability of the administrative agencies with specialized expertise in the area in question. The financial meltdown in 2008 was caused, in part, by government policies that changed the behavior of market participants. ${ }^{324}$ It is doubtful that the combination of federal backing for mortgages, federal insurance for bank deposits, and the repeal of the GlassSteagall Act, among other federal actions, would conspire someday to almost destroy the economy was foreseen by most policy experts. ${ }^{325}$ Chevron was an exercise in judicial humility. Hobby Lobby Stores was not.

Finally and ironically, Hobby Lobby Stores may inhibit agencies from voluntarily devising accommodations for religious organizations. After all, the Court in this case hung the Department of Health \& Human Services by its own petard. The very accommodation that the agency developed for religious organizations was used by the Court as proof that the agency's contraception mandate was not the least restrictive means of achieving the objectives of the Patient Protection and Affordable Care Act. It is quite possible that this lesson is not lost on this or other agencies when they draft rules to implement provisions that may burden religious practices.

\section{CONCLUSION}

It is beyond dispute that the Patient Protection and Affordable Care Act, whether or not one agrees with its public policy rationale or the manner in which it seeks to achieve its objectives, inserts the government squarely into the employer-employee relationship with respect to health care. RFRA is a broad law that is extremely solicitous of religious freedom. These two statutes will collide often and, most likely, over insurance coverage requirements that go beyond contraception coverage. Constitutionally, the Court, in the clash between generally applicable duties and religious freedom, gave the nod to the former. RFRA changed the ground rules but without nuance or context. Hobby Lobby Stores offered the Court the opportunity to place some principled limitations on RFRA. Unfortunately, it was a missed opportunity.

324. A detailed discussion of the causes of the 2008 financial crisis is well beyond the scope of this work and this author's expertise. For an entertaining examination of the factors that contributed to the financial crisis, including greed, misaligned incentives, misguided government programs, and hubris, see generally ANDREW Ross SORKIN, TOO BIG TO FAIL (2011).

325. Id. 